\title{
Post Pandemik Dönem Kamusal Alan Tasarımının Aldo Rossi Aforizması Üzerinden Okunması
}

\author{
Elif Sertsarı Aslan ${ }^{1}$ \\ ORCID: 0000-0003-3947-0440
}

\author{
Emel Birer ${ }^{2}$ \\ ORCID: 0000-0003-0152-3690
}

Öz

Modern Dönem, özellikle Avrupa'da Reform ve Rönesans hareketleri ile yükselişe geçen Sanayi Devrimi'nin etkisinde toplumun gündelik hayatına sizdlğı ekonomik, siyasi, sosyolojik ve psikolojik anlamda değiş̧imler yarattı̆̆ kırılma noktasın oluşturmuştur. Kırılma noktasını akıbet olarak tanımlayan Stavrides'in görüşüne göre "akıbet" (Stavrides, 2016, s.70), bir kentin değişmez çalş̧ma sisteminin ve kaliplaşan düzeninin çatırdamast için gerekli görülen bir kavramdir. Günümüzdeki kurlma noktası ile ilişkilendirildiğinde ise "Covid-19 Pandemisi"ne karşllk geleceği söylenebilir. Bu çalışmanın amacı, pandemi süreci ile tekrar yaşanan kirlma noktasından doğan akıbetin kamusal alanlarn yeniden tasarlanmasinda oluşacak olası faydalarım ortaya çıkarmaktır. Modern Dönem öncesi kent ve kamusal alan ilişkileri, çalş̧manın söylem analizi yöntemini belirleyen Aldo Rossi'nin "Özne -Nesne ve Bağlam ilişkisi" (Rossi, 1982, s.4) aforizması üzerinden okunarak, post pandemik dönem ile ilişkileri ortaya koymaktadır. Çalışmanın bulgularn, post pandemik dönemde tasarlanacak kamusal alanlar için örnek alnması gereken bağlamin Modern Dönem öncesinde de bulunduğunu ve yapılı çevrenin açık alanlar ile ilişkisini birbirine entegre etmenin yollarmı göstermektedir.

Anahtar Kelimeler: modern dönem, covid-19 pandemisi, kamusal alan, akıbet, öteki mekân

\footnotetext{
${ }^{1}$ Mimar (Yüksek Lisans Öğrencisi), İstanbul Kültür Üniversitesi, E-mail: elifsertsari@gmail.com 2 Prof. Dr., İstanbul Kültür Üniversitesi, E-mail: emelbirer@gmail.com idealkent @ Kent Araştırmaları Dergisi (Journal of Urban Studies) http://idealkentdergisi.com 


\title{
Reading Post Pandemic Period Public Space Design through Aldo Rossi's Aphorism
}

\author{
Elif Sertsarı Aslan 3 \\ ORCID: 0000-0003-3947-0440
}

\author{
Emel Birer 4 \\ ORCID: 0000-0003-0152-3690
}

\begin{abstract}
The Modern Period constituted breaking point where the daily life of tsociety under the influence of the Industrial Revolution, which rose with the Reform and Renaissance movements in Europe, and created economic, political, sociological and psychological changes. According to Stavrides the breaking point is "Fate" (Stavrides, 2016, p.70). Fate is a concept deemed necessary for a city's constant working system and stereotyped order to crack. When it is associated with today's breaking point, it can correspond to "Covid-19 Pandemic". The aim of this study is to reveal the possible benefits of fate arising from the breaking point experienced again with the pandemic process in the redesign of public spaces. Pre-Modern City and Public sphere relations, which can be reference to proposals can be read through the aphorism "Subject-Object and Context relation" (Rossi, 1982, p.4) of Aldo Rossi, who determined the discourse analysis method of study, and its relations with the Post Pandemic period synthesizes. The findings show that the context that should be taken as an example for public spaces to be designed in the Post Pandemic period also existed before the Modern Period and the ways of integrated relationship of built environments with open spaces.
\end{abstract}

Keywords: modern period, covid-19 pandemic, public space, fate, other space

\footnotetext{
${ }^{3}$ Architect (M Arch Student ), Istanbul Kultur University, E-mail: elifsertsari@gmail.com

${ }^{4}$ Prof. Dr. Istanbul Kultur University, E-mail: emelbirer@gmail.com

idealkent @ Kent Araştırmaları Dergisi (Journal of Urban Studies) 


\section{Giriş}

Düzen belirleyici doğanın milyonlarca yıl süren ve yaşantıların fark edemeyeceği yavaşlıktaki değişim süreci, modernitenin enstrümanlarıyla insanoğluna geçmiş ve düzen belirleyici yine insanoğlu olmuştur. Bu durum değişim kavramını deneysel bir alana taşımış ve öncesinde olamayacağı bir hıza ulaştırmıştır. Modern Dönem, kent ve kır yaşamını toplumsal ve sosyolojik açıdan etkileyerek bir yandan yeniliklere açarken diğer taraftan birçok hasarlar bırakmış ve bu hasarlar zamanla iyileştirilmesi güç bir durumu oluşturmuştur. Özellikle Modern Dönemin yaşam standartları, ekoloji üzerinde geri dönüşü olmayan tüketim anlayışına, doğa ile kopuk yaşantılara, modern insan figürünün duygusal ve etik değerlerinin değişerek yeni postinsan haline gelmesine sebep olmuştur.

Çalışma, Modern Dönemin hayatlara eklediği olumsuz şartları iyileştirecek kavramın bir akıbet olduğunu belirtirken, "akıbet" kavramın Stavrides 'in tanımına göre "yeni bir mekânsal deneyimi oluşturacak bir sebep" olarak görmektedir (Stavrides, 2016, s.70). Bu değişim aynı zamanda kentsel tasarımcılara şehirlerin fiziksel çevresini proaktif ve temelden yeniden şekillendirme firsatı da sunmaktadır (Abusaada ve Elshater, 2020, s.1). Dolayısı ile belirli sebeplere dayanan kırılma anlarının (dönemsel değişimler, salgın hastalıklar, göç vb.) oluşturduğu olumsuzlukları yaşanabilir bir çevreye dönüştürme yolundaki arzular, çalışmanın sorularını oluşturmakta ve gerekli çözümler için büyük önem taşımaktadır. "Covid-19 kırılma noktası ile beraberinde tasarlanacak kent/kentsel ve kamusal alanlar için öngörülebilecek tasarılara geçmişten örnek teşkil eden referanslar bulmak mümkün müdür?" sorusuna verilebilecek yanıt, oluşturulacak tasarının yeni bir söz söylemekten çok, yaşanabilirliği teyit edilmiş bir deneyimi barındırmasına olanak sağlayacaktır. Bu olanak Post-Pandemik Dönemin kent/kentsel ve kamusal alanlarının sürdürülebilirliği açısından oldukça önemlidir. Çalışma sorusu ile ilişkili olarak oluşturulan hipotez, geçmişten alınacak referanslar için kullanılan "akıbet" kavramı ile kırılma noktalarını sorgulayan literatür taramasından elde edilmiş ve örnek kırılma anının "Modern Dönem" olduğunu vurgulamaktadır. Modern Dönem öncesindeki kent/kentsel ve kamusal alan ilişkileri hipotezi oluşturan önemli bir bulguyu da içerir. Geliştirilen hipotez, "Bir kırılma noktasını tanımlayan "Pandemik Dönem" in başka bir kırılma noktası olan "Modern Dönem" ile benzerliklerinin aksi yönünü destekleyerek Pre-Modern ${ }^{5}$ Dönem şartlarının günümüze

5 Pre-Modern Dönem: Modern Dönem kırılmasının öncesinde yaşanan dönemi tanımlamaktadır. Metinde Modern Dönem Öncesi olarak da geçmektedir. 
taşınarak ancak bugün yaşadığımız kırılma noktasında gelişen şartlar ile birleştiğinde yaşanabilir tasarım önerileri sunacağını savunmaktadır.

Dünya, tarih boyunca birçok salgin hastalıkla mücadele etmiştir. Pandemi olarak adlandırılan, geniş alanlarda etkisini gösteren ve birçok kişiyi/olguyu/nesneyi etkileyen bu salgın hastalıklar, küresel anlamda güçlü değişimler yapma potansiyelini de içinde barındırır ve mekanları değiştirerek "öteki mekân" haline gelmesini sağlar. Bu çalışmada mekânı ötekileştirmek ve dönüşümü sağlamak için, bugünün öznesini geçmişin nesnesi ile buluşturarak "Modern Dönem Kırılması" nın yaşandığı dönemin bağlamına bakmak iyi bir başlangiç olacaktır.

\section{Yöntem}

Yeni tasarım önerilerine referans olabilecek Modern Dönem öncesi kent/kentsel ve kamusal alan ilişkileri, çalışmanın söylem analizi yöntemini belirleyen Aldo Rossi'nin (Rossi, 1982, s.4) “Özne- Nesne ve Bağlam İlişkisi” üzerinden yola çı1larak, "Nesneler" (kentler), "Özneler” ile (kent kullanıciları) bağlantı kuramıorsa gerekli "bağlam"ın oluşması için "tarih"e gidilmesi gerektiğini vurgulamaktadır. Buradaki söylem sosyal, politik, kültürel, ekonomik alanlar gibi, yaşamın tüm ilişkisel girdilerinden oluşmaktadır (Sözen, 1999, s.100). Bu girdiler, Modern Dönem öncesi nesneleri ile yeni tasarım anlayışı ve dönüşüme ihtiyaç duyulan bugünün özneleri yeniden yorumlanmış, gerekli olan yaşanabilir kent ilişkisine referans oluşturmuştur. Modern Dönem öncesi insanı ile benzerlik gösterebilen "Özne", komşuluk ilişkilerine başlayarak çevresine olan güvenini arttırmış, salgının her kesimi etkilemesi ile eşitlik kavramını gözlemlemiş, doğanın ve sosyal alanların önemini fark etmiş, tüketim anlayışını sorgulayan bir karaktere dönüşerek yeniden yapılandırılmıştır. Dönüşüme uğrayan yeni insan tipinin ise, salgindan sonra tasarlanacak yeni "Nesne" ye yani kent/kentsel ve kamusal alanlara ihtiyacı vardır ve "Tarih" teki nesneleri bugüne getirerek bağlamı kurmak için yaşanabilir çevre zamanla oluşturulacaktır (Şekil 1).

Covid-19 pandemisinin etkilerinin yaşandığı süreç içerisinde zorunlu olarak ihtiyaç duyulan kurallar ve salgının etkileri neticesinde aranan kent/kentsel ve kamusal alanların gereklilikleri çalışmanın tasarı bağlamını oluşturmaktadır. Sağlıklı toplumsal ilişkilerin, kültürel sürekliliğin de devam edebilmesi için yapılan araştırma değerlendirmelerinde çözümün Rossi'nin deyimiyle bellekte var olduğunu görebilmek mümkündür. Bu sayede tarihsel bellek, oluşturulacak yeni yaşam formunu günün özne ve nesne ilişkileri içerisinde bulabilecektir. 

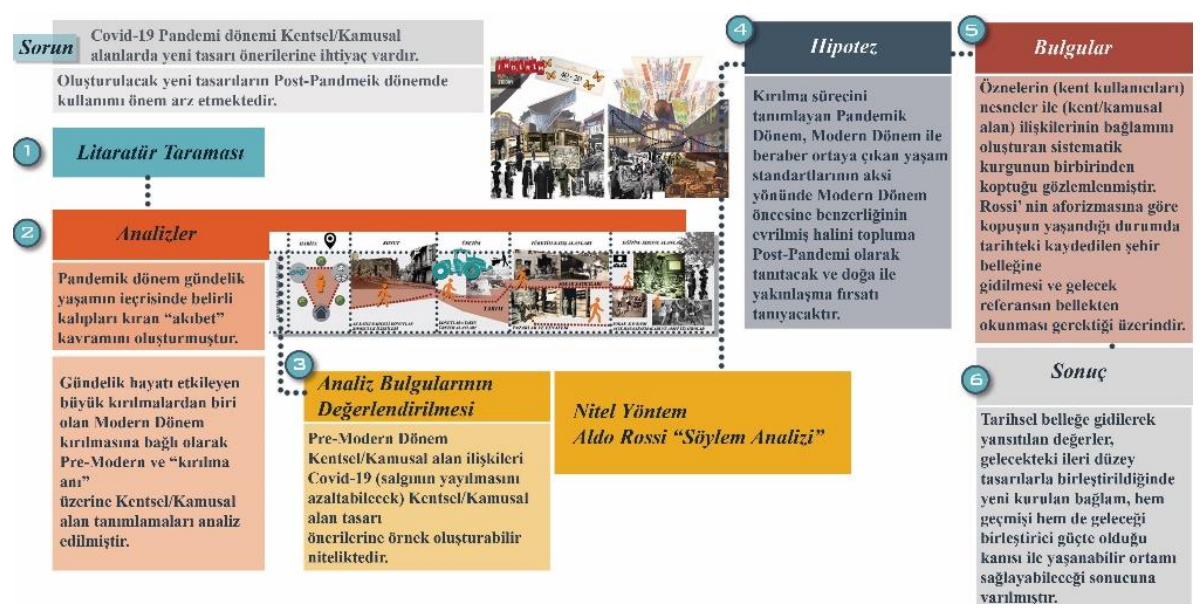

Şekil 1. Metodoloji (Sertsarı; Birer, 2021)

\section{Modern Dönem}

Modern Dönem' in yaratmış olduğu değişim ve dönüşümleri ile gelişen yeni yaşam döngüsünü tarifliyor olması bir geçişi ifade ederken, çalışmanın içerisinde kırılma noktası olarak tanımlanmaktadır. Kırılma noktaları, yaşamı değiştirip dönüştürme özelliğini içinde barındır ve bu değişim toplumsal hafızayı etkileyerek yeni gündelik yaşam formunu belirler. Belirlenecek yeni formda Modern Dönem' i anlamak, kent kentsel/kamusal alan tasarımlarına 1şık tutacak yeni hafizayı oluşturmada oldukça etkili olacaktır.

Çalışmada kabul edilen bir diğer kırılma noktası olan, Covid-19 Pandemisi için tasarlanacak kent kentsel/kamusal alanlarda öngörülebilecek tasarılara geçmişten örnek teşkil eden referanslar alındığı takdirde hem toplumsal yaşamın sürdürülebilirliği hem de yaşanabilirliği teyit edilmiş bir ortamı sağlamak mümkün olabilecektir. Bu sebeple Modern Dönem' i inceleyerek öncesinde var olan yaşamı kavramak oldukça önemlidir. Modern Dönem gündelik yaşam içerisinde kent kentsel/kamusal alan ile ilişkileri kullanım haritası baz alındığında kullanıcnun konut ve konut çevresi ilişkileri, üretim ve tüketim alanları, sosyal alanları, eğitim alanları dönemin bilgileri hakkında genel çerçeveyi belirleyen alt başlıklar olabilmektedir.

\section{Bir Kınlma Noktası Olarak "Modern Dönem"}

Modern Dönem, Avrupa'da Ortaçağ' dan sonra Reform ve Rönesans hareketi ile beraber yükselişe geçen bir süreci başlatmış ve Modern Dönem ile birlikte üretim tarzındaki değişim, kentlerdeki yapısal değişimi (dönüşümü) getirmiştir. Sanayi devrimine kadar evine yakın üretim yapan insan, üretim alanlarını kay- 
dırmış konut ile arasında ilişkisel ağlar kurmuştur. 18.yy sonunda ilk olarak İngiltere'de etkisini göstermiş olan Endüstri Devrimi, toplum yerleşimlerini sosyal ve fiziksel anlamda tamamen değiştirmiş̧tir (Doğrucan, 2014, s.8). 19.yy'ın başlaması ve sanayileşme hızı ile beraber kentler daha çekici hale gelmiş ve fiziksel anlamda oldukça fazla değişimleri meydana getirmiştir. Kursal bölgelerde yaşanan tarım modernisazyonu ve buharlı makinelerin icadı ölçekli olan atölyelerin büyüyerek üretim yapan atölyeler haline gelmesinin ardından kitle üretimi yapabilen fabrikaların oluşmasına sebep olmuştur. Dolayısı ile Endüstri Devrimi kol gücünden makine gücüne geçişi de temsil etmektedir (Özdemir ve Gökmen, 2016, s.119).

Kırsaldan kente büyük göçten sonra kentlerin fiziki ve sosyal anlamda tüm düzenleri bozulmuştur. Bellekte var olan düzenin yerini anlaşılmaz kent düzeni ile değiştirmesi sonucu çarpık bir kentleşme oluşmuş ve dönemin ekonomisini içinde barındıran yapı malzemesi beton yığınına dönüştürmüsstür. Fabrikaların kurulması ve bu fabrikalarda çalışacak işçiler için konutların yerleşimi tamamen o dönemin kentsel özelliklerini içermiştir. İngiltere'de başlayan bu sıkıntılı süreçte avlulu sıra konutlarda yaşayan işçilerin yoğunluğu bir yatakta çok fazla kişinin birlikte paylaştğı ortamları doğurmuştur (Baba, 2020, s.139). Oluşan modern kentlerdeki karmaşıklık, belirsizlik, güvensizlik yalnızlı̆̆ beraberinde getirmiştir. Çünkü kentler artık çok farklı kültürdeki insanların bir araya gelmesi ile oluşmuş karma bir topluluğu ifade etmektedir (Kaldık, 2017, s.28). Bu sebeple toplumsal entegrasyonun basit nedenlerinden biri için ekonomik modernleşme ile oluşan yeni kentleşme, mal ticareti ile beraber oluşan haberleşme ağı ve insanlar arası ilişkilerin yayılması denilebilir (Habermas, 2002, s.20).

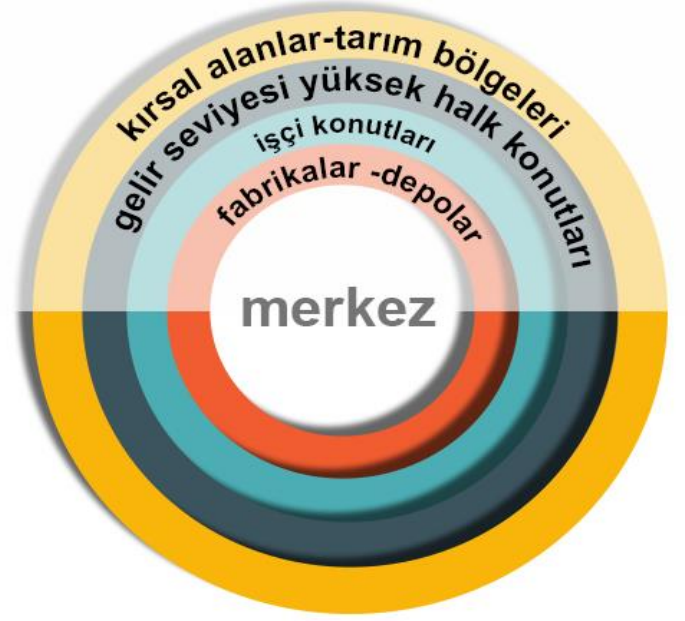

Şekil 2. Sanayi Devrimi Avrupa kenti yerleşim düzeni (Sertsarı, 2021) 
Sanayi Devriminde Avrupa kent düzeni merkeze yerleşen fabrikalar ve depolar ile beraber değişime uğrarken kent kullanıcıları çeperlere taşınmıştır. Gündelik yaşamın içerisinde fabrikalar ile sirkülasyon ağını oluşturan işçi konutlarının fabrikalara yakın yerlerde konumlandığını görmek mümkündür. Tarım alanları ise, kentin en dış çeperinde yer almaktadır (Şekil 2). Demir yollarının döşenmesinden önce merkezden taşınan zengin kent kullanıcıları merkezi kendi özel araçları ile kullanabilirken, demir yollarının yapılmasından sonra fakir halkın da çeperlere yerleşmeye başlandığı görülmüş ve bu durum sonrasında tekrar merkezdeki konutların değerini yükseltmiştir. Bir sonraki evrede fabrika ve işçi, konut yerleşimini dışa kaydırmış ve merkezin değeri bir kez daha artmıştır. Dolayısı ile yeşil alana sahip bahçeler, artık el değmemiş alanlar olmaktan çıkmış yoğun alanlara dönüşmüştür (Baba, 2020, s.132). 19.yy'ın modernliği, buharlı makineler, demiryolları bunlarla büyüyün kent çeperleri, ekonominin değişimi, günlük iletişimin arttığ telgraf ve telefonun kullanımı gibi gelişimler ile birlikte en gösterişli büyümenin gerçekleştiği evredir (Berman, 1994, s. 32). Hızla okuyucusu artan ve çeşitlenen gazeteler, reklamlar, ilanlar, çeşitli fotoğraf ve baskıların ardından gösteri mekânları, tiyatrolar, operalar, salon sergileri gibi daha sonrasında yerini galerilere bırakacak olan seyirler gerçekleşmiştir (Baudelaire, 2009, s.41). Modern dünya insana birçok sorumluluklar da getirmiş, soyunun ya da asaletinin bir şey ifade etmediği ve herkesin standartlaştığı bir döneme geçiş olmuştur. Modern insan artık kendi kendini yarg1layan kişi haline dönüşmüş, kendi karakterinden çıkarak farklı bir karaktere büründüğü ikiz kişiliği oluşturmuştur (Acar, 2017, s. 34). İkiz kişiliğinin içerisindeki modern insan güç, gelişme, dünyayı değiştirme gibi duyguları hissederken kendisine ait olan özelliklerinin yitip gittiği tek tip insan formuna girmiştir. Kültürel, sosyal anlamda farklı olan toplulukları birleştirdiği düşünülse de aslında bu bir bölünmüşlüğün birleşimini yaratmaktadır (Berman, 1994, s. 31).

Standartlaştıılma bellekte var olan davranışların kendiliğinden olma durumunu zedeleyerek kurallar içinde hapsetmiş ve dünya öngörülmez soğuk bir hal almıştır. Gündelik yaşantıda geleneklerin, din ve kültürün yeri aşınmıştır (Aydoğan, 2013, s.6). 


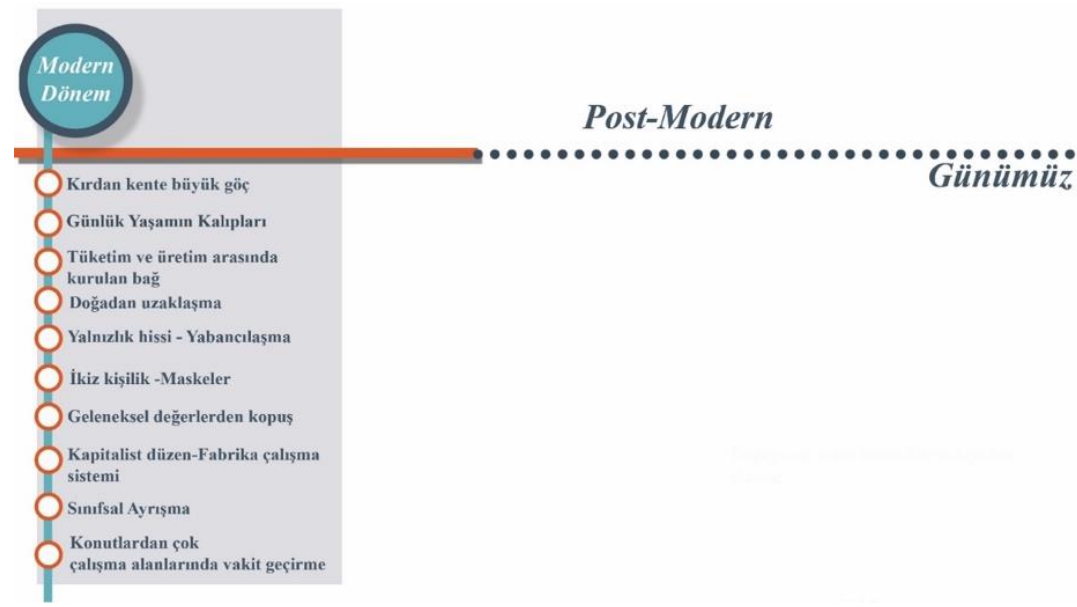

Şekil 3. Modern Dönem belirleyicileri (Sertsarı, 2021)

Modern Dönem ile birlikte gerçekleşen değişimi dönüşümü yansitan en önemli olgu kırdan kente büyük göç ile beraber gündelik yaşamın kalıplarına uyulması zorunluluğu ve bununla beraber yeni bir yaşam formunun oluşmasıdır (Şekil 3). Bu yaşam formu, tüketim ve üretim arasında kurulan bağ 1 değiştirmiş ve doğadan uzaklaşılarak kalabalıklar içerisinde kendini yalnız ve yabanc hisseden şehir kullanıcılarını oluşturmuştur (Şekil 4. 1, 2, 3). Yaşanan değişim, çalışma sisteminin kapitalist düzenin baskısında kaldığı, sınıfsal ayrışmaların çokça görüldüğü mekanik bir yaşamı (Şekil 4. 4, $5,6)$ tariflemektedir. Tarif edilen yaşama dair bellek fotoğrafları söyleme örnek teşkil eden gündelik yaşam kesitlerinde görülebilmektedir.
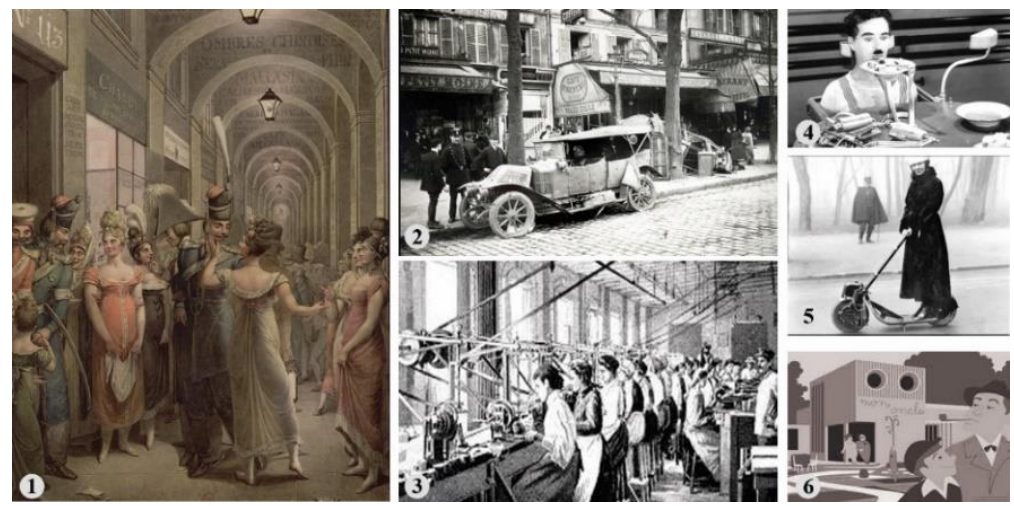


\section{Şekil 4. 1- ("Le Palais-Royal”, 2016) 2- (“L'Illustration”, 2018). 3-(“1768-1771: Sanayi”,} 2019 ) 4-(“Worker feeding machine" , 2011) 5- ("Étonnant : la trottinette", 2019) 6- (“Mon Oncle", 2010)

Modern kapitalist bir hayatın bağlamında toplum, yaşamsal değerlerinden koparken, sistemin bütünselliğinde kolonileşme içerisinde kalmış, gündelik yaşam ile sistem arasında sıkışmıştır (Şimşek, 2008, s.1).

Habermas'in tanımina göre modernizm ve modern olma durumu, farkındalık ve hazcı güdülerin fark edilerek serbest bırakılmasını teşvik eder ve toplumun işlevsel ve rasyonel kavramına karşı onları kışkırtır (Habermas, 1996, s.42) Batı'da ortaya çıkan modernizme karşılık oluşan sanayi ve sosyoekonomik koşul Türkiye için geçerli olmamasına rağmen 1950'lerden sonra konut normunun içerisine ayrı misafir odaları, mutfakta yemek yenmeye başlanması veya tuvaletlerin Batı tuvaletlerinin tarzının yanında alaturka tuvaleti de barındırması gibi batılı yaşama duyulan inancın melezleşmiş bir ifadesini oluşturmuştur (Bozdoğan, 2003, s.5). Modern konutun geleneksel ev hayatına entegre edilmeye çalışıldığ gündelik hayat düzenini etkileyen birebir etmenleri oluşturmaktadır.

\section{Modern Dönem Kent / Kentsel ve Kamusal Alanlar}

Modern Dönemi anlamak için kenti yerelliği ve kendi kıyafeti içerisinde çevre ile uygun evrensel ve yapısal bir sistem olarak düşünmek oldukça önemli bir husustur (Hays, 2015, s.131). Bu yerelliğin içerisindeki durum toplumsal ilişkilerin bir ifadesi olarak tanımlanabilirken aynı zamanda topluma bir tepki olarak da karş1llk veren bir diyaloğu oluşturur (Soja, 2017, s.107). Bu bağlamda ilişki kurulabilecek kent tanımlaması Henri Lefebvre'nin örneklemi üzerinedir. Örneklemeye göre: Kenti yürürken birkaç işaret noktası koyarak başlangıç noktasını tanımlar. Sıfır noktasında insan toplulukları vardır; balık tutan, avcı, çoban. Bu kişiler mekanları tanımlayarak çeşitli isimler vermişlerdir. Daha sonrasında bu isimlere göre çeşitli topolojiler ${ }^{6}$ oluşmuş ve bu toprak yerleşimi köylüler tarafından sahiplenilerek mükemmelleştirilmeye çalışılmış, yavaş yavaş köy yaşantısından kent yaşantısına geçilmeye başlanmıştır (Lefebvre, 2015, s.85). Kentin köy hayatına sızması köylüyü, geleneksel hayat öğelerinden yoksun bırakarak, köylerin de kendi özelliklerini yitirmesine sebep olmuş ve kırsal toplum kente ayak uydurmaya çabalarken kimi zaman kendilerini içlerine kapatmışlardır.

6 Topoloji: Parsel sınırlarının koordinat yöntemleri ile belirlenerek üç boyuttaki durumunu tanımlayan formlardır. 
Kentlerin tanımlanmasında omurga görevini gören sokak, sadece bir sirkülasyon alanı değil, aynı zamanda bir buluşma mekanıdır ve sokak olmadığı takdirde buluşmanın da gerçekleşmesi pek mümkün değildir (Lefebvre, 2013, s.22). Sokak, buluşma kavramını sadece tercihen değil, birlikte olma olgusunu zorla kabul ettirmektedir (Şekil 5. 7). Komşuları idare etmek, kimlik tanımlamasının içerisine sokularak bakkal, anne, çocuk, papaz, emekli, doktor şeklinde adlandırılmak modern insana yükler katarken etiketler ile beraber yeni maskeler oluşturur (Certeau, 2009, s.39). Toplumsal olarak değerlendirildiğinde ise özgürlüğü, düzensizlik şeklinde de tanımlamak mümkündür. Sokak kentin bir mekânı ve sözün söylendiği yer, işaretlerin ve kelimelerin mübadele yeridir. İnsanlar sokakta sadece karşılaşmazlar birbirlerine yaklaşırlar (Lefebvre, 2013, s.22). Sokak ilişkileri kuvvetlendiği takdirde kentin suç oranı azalarak kullanıcıların birbirine karşı güveni de artacaktır.
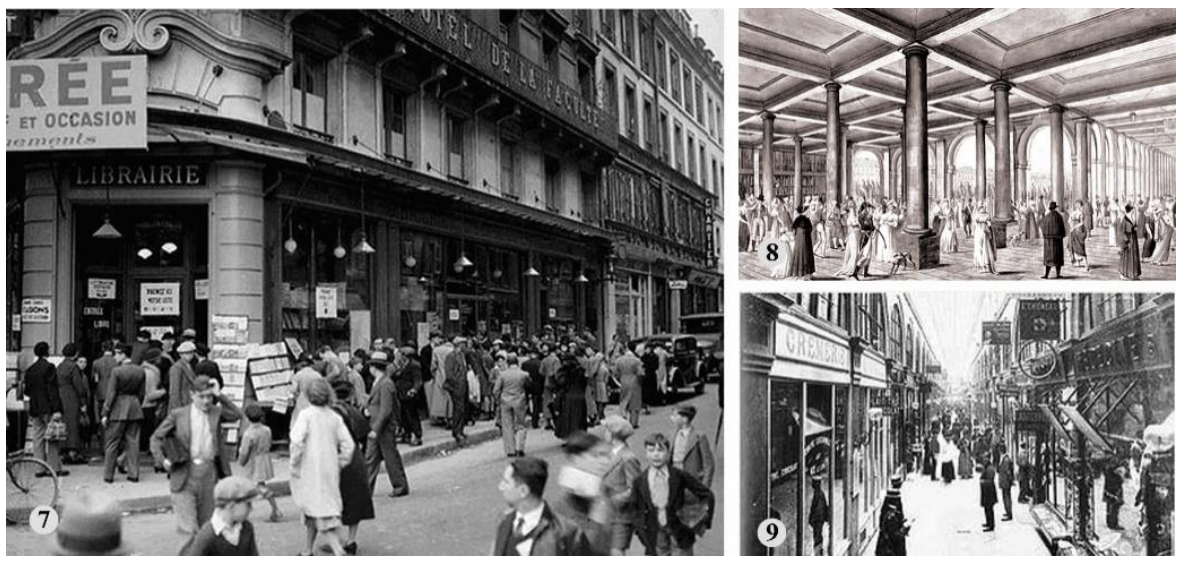

Şekil 5. 7- (“Caen et ses", 2017) 8- (“Les galeries du", 2021) 9- (“Caen et ses", 2017)

Dönem dönem farklı anlamlar ifade eden sokak, Antik dönemlerde tap1nakların, agoraların bahçelerini birleştirdiği yerleri tanımlarken, Ortaçă̆' da hem satıcı hem de üretici zanaatkarların işgal ettiği alanları oluşturmaktadır. Zamanla sokak, mağaza vitrinleri sayesinde bir sergi haline gelmiştir (Şekil 5. 9). İletişim mekânı olarak da tanımlanabilecek sokak kavramı, gündelik kullanıcının kullanımını hem zorunlu kılar hem de baskı altında tutar. Bu sebeple de iktidarın kendini tehdit altında hissettiğinde ilk yapacağı şey sokakta toplanmak ve gezinmeyi yasaklamaktır. Eğer karşılaşma anlamını taşıyorsa o zaman da yolu yayalar ve araçlar olarak ikiye bölerek kullanılarak bu anlamı kaybettirilir. Sanayi devriminden sonra sokak, iş ve ev arasında geçiş alanından başka bir şey değildir (Lefebvre, 2013, s.23). Kamusal ya da 
özel sosyal kümelenme terimleri kamusal alan (Şekil 5. 8) ve özel alan, kutuplaşmalarını kaybetmeden yakın bir ilişki içinde gelişirken, 'kamusal' ya da özel olarak nitelendirilemeyen yaşam sektörleri anlamlarını yitirir (Rossi, 1982, s.86).

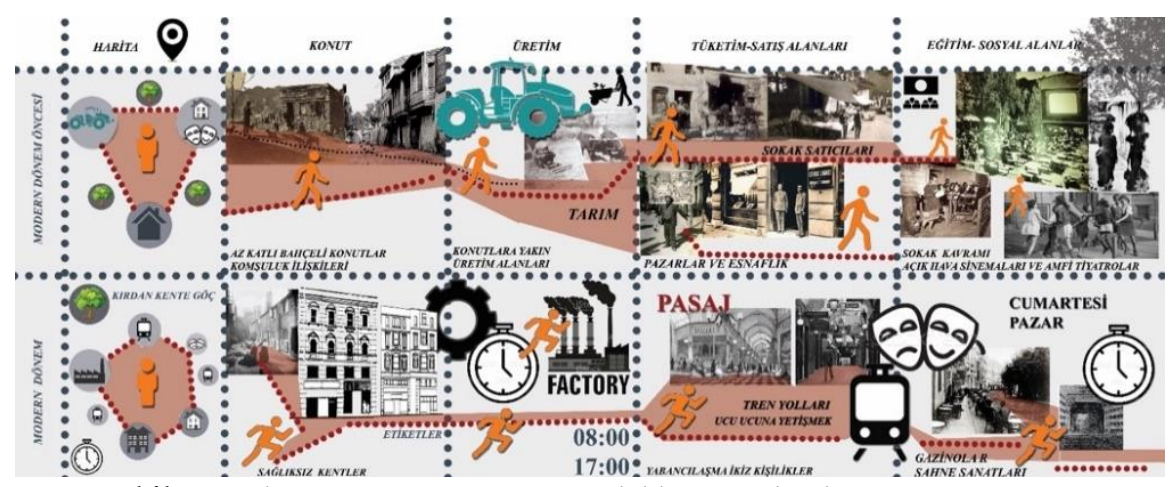

Şekil 6. Modern Dönem ve öncesi gündelik yaşam bağlamı (Sertsarı, 2021)

Modern Dönem öncesi kullanıcı haritası bağlamı (Şekil 6); gündelik hayatın içerisinde yerleşim yeri konutlar ve konutların açık mekanla olan ilişkileri, yerleşim yerinden ayrılarak üretim yaptı̆̆ alanlar, üretimin üzerine gerçekleştirilecek satışın yapıldığı alanlar ve tüm bunlar ile ilişki kuracak sosyal alanları içermektedir. Konutların ve üretim yapılan tarım alanlarının yakın olduğu, sirkülasyon alanını tanımlarken sosyal alanlar mahallelerin içerisinde güvenli ortamı teşkil etmektedir. İnsan ölçeğine uygun konut yapıları sokak ile iletişim halindedir ve olabildiğince yeşil alana dokunmaktadır. Satış alanları açık pazar yerlerinde veya mahalle satıcıları ile yapılmakta, küçük esnaf mahalleli ile sosyolojik bir ilişki kurmaktadır. Mahallelinin eğlencesi olan açık alandaki akşam sinemaları kullanıcıları birbirine bağlamakta ve güven ortamını oluşturmaktadır. Tüm bu modern öncesi kullanıcı haritasının içerisindeki hareketlilik her zaman açık alan ile ilişkili yaşam alanları ile yakın ağlar kurmaktadır. Modern Dönem gündelik kullanıcı haritası içerisindeki bağlam ise (Şekil 6); kentin kullanım ağlarını genişletmiştir. Kırdan kente büyük bir göç yaşanan Modern Dönemde, açık alan ilişkisinin pasifize olunmaya başlandığı, gündelik hayat kalıplarının içerisinde kalan modern insanın çalışma hayatı ve evi arasında sıkışıp kaldığı söylenebilir. Modern Dönemde ortaya çıkan "boş zaman” kavramı, sosyal hayat için ayrılan zamanın dahi "Cumartesi" ve "Pazar" kavramı ile determine edildiği ancak bunlar için de kısttlı sürelerin olduğu bir zaman diliminin temsilidir. Kalabalık nüfusa hitap eden konut yapıları, güvenlik ihtiyacını ortaya çkarmış ve komşuluk ilişkilerimi en aza indirgemiştir. Modern 
Dönemde mekânsal olarak üretim nesnelerinin sergilenmesi için alan yaratma çabasına karşılık gelen "Pasaj" kavramı (Şekil 7. 10, 11, 12), satış alanlarını kapalı alan ile ilişkisel ortamı hazırlayarak gelecekte "avm" olarak tanımlanan yapılarına gerekli referansı oluşturmuştur (Şekil 6).

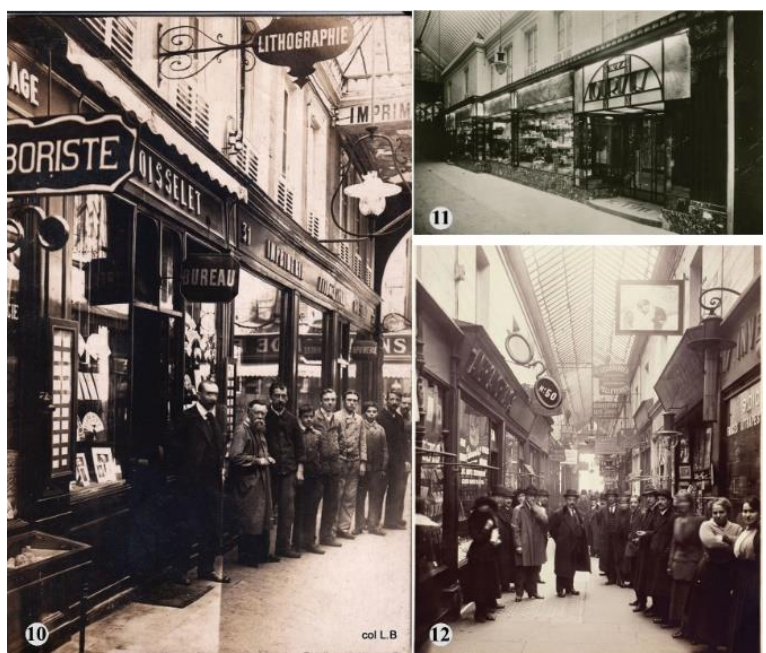

Şekil 7. 10-12- (“Lithographie imprimerie oisselet”, 2016) 11-(“Intérieur du passage”, 2017)

Sanayileşmenin giderek genişlemesi ile belirleyici aşamalardan geçen yapı tiplerinden ev ve işyerinin kesin bir şekilde ayrılması ile beraber komşuluk ve mahalle ilişkileri eski halinden uzaklaşmıştır. İlk kolektif çalışma türlerinin ortaya çıkmasına, her zaman işyerinin yakın çevresinde olmayan bir konut seçeneği eşlik etmekte, bu gelişmeye paralel olarak, ticari eşya üreten iş yerleri ile üretmeyen işyerleri arasındaki ayrlık da görülmektedir (Rossi, 1982, s.159). Bu durumda belirleyici olan Modern Dönem üretim tarzındaki değişim, kentlerdeki yapısal değişimi (dönüşümü) de zorunlu kılmış, üretim ve konut ile arasında yeni ilişkisel ağlar kurulmuştur (Adilhan ve Ünverdi, 2018, s.2). Şehrin dönüşümünün bir diğer aşaması ise, bireysel ulaşım araçlarının geliştirilmesi ve iş yerine ulaşımın toplu taşıma araçları ile sağlanması olmuştur. Yerleşim yerinin seçimi, çalışma yerinden giderek daha fazla bağımsız hale gelmiştir. Bu arada, halen merkezde konumlanma eğiliminde olan hizmet faaliyetleri gelişip birincil önem kazanırken, şehir dışında yakın kırsalda konut arayışı her geçen gün güçlenmiştir. İş ve konumu, konut seçiminde giderek artan bir şekilde ikincil bir rol oynamaya başlamış, vatandaş banliyö olgusuna yol açarak, dilediği bölgenin herhangi bir yerine taşınarak ikamet ve iş ilişkisi kurmuştur (Rossi, 1982, s.159). 
Burada ihtiyaç duyulan açık alan ilişkilerinin örtüştüğü dönemin Modern dönem öncesine ait olduğu açıkça görülmektedir. Modern Dönemden günümüze gelene kadar açık alan ve özne kullanımının belirgin bir biçimde etkisini gösterdiği akıbetlerden biri bugün yaşanılan covid-19 pandemisidir.

\section{Yöntem: Aldo Rossi “Özne-Nesne İlişkileri ve Bağlam”}

Modernizm sonrası Avrupa şehri ölülerin evi haline gelmiş, tarihi işlevi sona ermiştir. Dev veya kolektif bir hafıza evi olarak, bir fantezi ve yanılsama yeri, geçiş halleri olarak hem yaşam hem de ölümün bir analoğu olmasından kaynaklanan psikolojik bir gerçekliğe sahiptir. Rossi için yazılar ve çizimler, bu devasa bellek evini ve çocukluk hayal ve umut evi ile illüzyon ve ölüm evi arasında karşılaşılan tüm o belirli yerleşim yerlerini keşfetme girişimidir (Rossi, 1982, s.2). David Harvey Umut Mekanları adlı kitabında Balzac' tan "Umut, arzulayan bellektir" şeklinde alıntılama yaparken (Harvey, 2008, s.1), Ojalvo, arzunun gerçekleşmesi için her zaman bir umudun olduğunu fakat bunun bir "muğlaklık" halini tanımladığını vurgulamaktadır. Muğlaklık, kent ile kentli arasındaki ilişkiyi bedensel olarak deneyimleyerek; zihin, mekân ve beden ilişkilerinin iç içe geçtiği bir hali tanımlamaktadır (Ojalvo, 2012, s.259). Mekân ve beden ilişkisi kuran, korunmuş veya patolojik kalıcılıklar, şehirdeki mumyalanmış varlıklar, genellikle kalıcı karakterlerini belirli bir bağlam içindeki konumlarına borçludur. Bu anlamda, çağdaş "bağlamcıların" yarı-doğalcı şehirciliği, Rossi'nin görüşüne göre, evrimsel zaman kavramına diyalektik olarak karşı çımaktadır. Rossi için gerçek zaman, belirli bir kentsel bağlamın düzgün bir şekilde sınırlandırılmış ve titizlikle gözlemlenen görüntülerini aşındırma ve onların yerini alma eğilimindedir. Ancak şehirdeki kalıclıklar sadece "patolojik" değil, bazen "itici" olabilirler. Hala yaşanabilecek bir geçmiş sağlayarak geçmişi bugüne getirmeye hizmet ederler (Rossi, 1982, s.3).

Geçmişi bugüne getirmek için kullanılan nesne kullanımda olduğu sürece tarih kavramı da var olmuştur. Deleuze çıkış felsefesinde geçmişi anımsayarak geleceğin hayal edilmesi üzerine zihinsel bir akıştan bahseder. Bu felsefede özne yerine beden önemlidir ve mekân zaman ve beden ilişkisi kurulur (Ojalvo, 2012, s.281). Ancak, biçim ve işlev koptuğunda ve yalnızca biçim yaşamsal kaldığında, tarih bellek alanına kayar ve tarih bittiğinde ise hafıza başlar. Böylelikle kentin biçimlendirildiği sürecin kent tarihi olduğu söylenebilir, ancak olayların birbiri ardına gelmesinin belleğini oluşturduğu bir gerçektir. Rossi'nin Fransız şehir coğrafyacılarından çıkardığı bir fikir olan "şehrin ruhu", tarihinde yatar; bu ruh bir kez form verildikten sonra bir yerin işa- 
reti olur. Kronolojik anlamda zaman klasik bir bağlama ve tarihsel anlamda modernist bir bağlama aitse, o zaman bir zamanlar tarihten çok bellekle ilişkilendirildiğinde, psikolojik bir bağlama geçer. Belleğin nesneye dahil edilmesiyle, nesne hem kendisi hakkında bir fikri hem de eski bir benliğin belleğini somutlaştırır. Tip artık tarihte bulunan tarafsız bir yapı değil, artık tarihin iskeleti üzerinde işlem yapmak için kullanılabilecek analitik ve deneysel bir yapıdır; bir aygıt, analiz ve ölçüm için bir araç haline gelmektedir (Rossi, 1982, s.4).

Rönesans'ta var olan bireysel özne (insan) ile bireysel nesne (ev) arasındaki ilişkinin artık kolektif psikolojik özne (modern şehrin nüfusu) ile tekil nesnesi (şehir, ama farklı ölçekte bir ev olarak görülen) için hümanist kentin içerisinde hiçbir şeyin değişmediğini ima etmektir. Özne ve nesne bağımsız olacaksa, daha önce tarafsız olduğu düşünülen özne ve nesnede bulunan güçleri üstlenmesi gereken artık süreçtir. Rossi bu yeni süreç fikrine tarihin ve tipolojinin unsurlarını yeniden dahil etmiş, ancak anlatı için bir nostalji olarak bakmamıştır. Bunun yerine tarih, durumu zaman ölçüsü olarak hizmet eden ve karşllığında zamanla ölçülen bir "iskelete" benzeterek, şehirde gerçekleşen ve gerçekleşecek eylemlerin izlerini taşıyan bir taşıyıcı fikri ile ele almıştır (Rossi, 1982, s.4). Şehrin düzeni, biyolojik bakımdan nitelenen nesnelerin ve onların öznelerle ilişkilerini düzenleyerek kayıt altına alan bir aygittır. Bu şehrin düzeni ve yasaları bireylerin kendi yaşam ve kaderini belirleyen yasalarla aynıdır (Hays, 2015, s.131). Rossi için mimarinin tarihi malzemesinde yatmakta ve analiz edilen nesnesi haline gelen de bu malzeme olmaktadır.

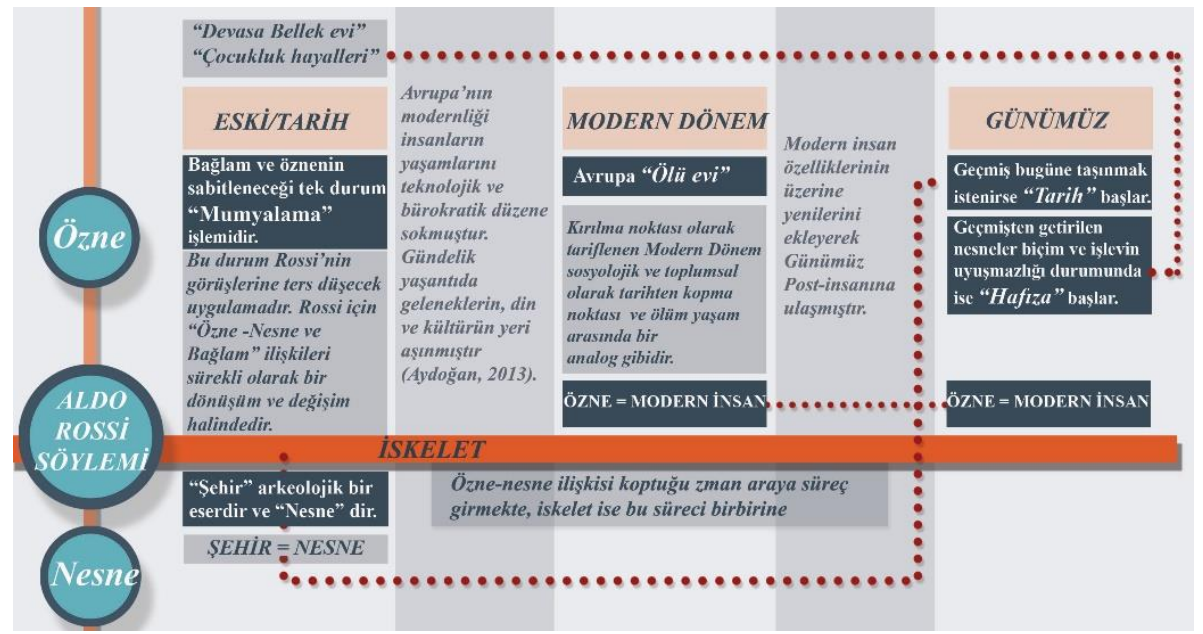

Şekil 8. Aldo Rossi - Söylem Analizi (Sertsarı, Birer, 2021) 
Aldo Rossi'nin "Ölü evi" şeklinde tariflediği Avrupa, öznelerin geçmişinden kopuşu ve "Modern insan" şeklinde tanımlanması ile beraber başlamaktadır. Geçmişten geleceğe doğru "iskelet" sistemle aktarılan özne ve nesnelerin ilişkileri kendi bağlamlarını oluştururlar. Fakat bu ilişkiyi Modern Dönem sekteye uğratarak dönemin kırılmasını meydana getirir. Geçmişinden kopan (Habermas, 1994, s.7) modern insan, özneler arasındaki ilişkiyi sadece gelecekte post insan ile kurarak onun determine edilmiş halini oluşturur. Bu sebepledir ki, Modern Dönem öncesi öznesi ile Modern Dönem öznesi birbiri ile ilişki kuramamaktadır. Tarihi ve hafızayı oluşturan ve bunları kayıt altına alan şehir, arkeolojik bir eserdir ve nesnelerden kalanları geleceğe aktarır. Özne ve nesneler arası ilişki kurulamadığı takdirde tarih ve hafızaya geri dönülerek gerekli referanslar alınabilir (Şekil 8).

Söylem analizi üzerine oluşturulan yöntemde, metodolojik ve kavramsal öğeler toplanarak sosyal hayata dair perspektifler sunulur ve bu durum söylemin üzerinde düşünülmesine ve söyleminin somutlaştırılmasına fayda sağlar. Söylem, iletinin tüm boyutlarını içeriği ile beraber değil söyleyenin otoritesi ve nereye dayanarak kime söylendiğinin amacı ile beraber yorumunu barındırır. Habermas'ın eleştirel teorisi ile de yakından ilişkili olan görüşüne göre, dil ve konuşma eylemleri, söze dökülmüş söylenen şeyler basit şeyler değildir ve sözcüklerin içerikten ayrı kendilerine ait bir ruhları vardır (Çelik ve Ekşi, 2008, s.100).

Çalışma kapsamındaki söylem analiz aşamalarının ilkini oluşturan yorumlama; çalışmanın ihtiyacını doğuran Covid-19' un etkilerine karşılık geliştirilecek yeni kent/kentsel/kamusal alanlar için yaşanabilirliği teyit edilebilecek mekânın varlığının araştırması üzerinedir. Bu aşamada yaşanabilirlik olgusunun keşfi Starvides'in "Akıbet" kavramı ile beraber gerçekleşen değişim dönüşümü yaşanan gündelik hayat içerisindeki açık alanlarla olan ilişkisini irdelenmektedir. Günlük hayatın içerisindeki kullanıma istinaden,

- Konut yaşamı ve konut çevresi kurulan açık alan ilişkileri,

- Konutunu gündelik oranda terk eden bireylerin çalışma hayatını oluşturan üretim mekânları,

- Üretimin satışa sunulduğu tüketim mekânları,

- Kent kullanicilarını bir araya getiren sosyal alanlar,

- Tüm bu maddeleri kapsayan gündelik hayat kullanıcısının haritasını oluşturur.

Bu haritanın kısıtları Pre-Modern Dönem kullanıcı haritası ile örtüşmekte ve diğer tüm ilişkiler ise Covid-19 salgınında ihtiyaç duyulan açık alan 
ilişkilerini oluşturduğu gözlemlenmektedir. Bu aşamada, Aldo Rossi'nin "İskelet" kavramının tanımlaması ile birlikte kayıt altına alınan şehir üzerinden "belleğin" ihtiyaç duyulan tasarı önerisine referans verdiği teyit edilmiştir.

Söylem analizinin ikinci aşamasını oluşturan yapılandırma, Covid-19 pandemi sürecindeki kullanıcı ihtiyaçlarına karşılık gelişen yeni "Özne", Modern Öncesi Dönemin gündelik hayat ihtiyaçları içerisindeki öznesine dönüşmüştür. Bu dönüşüm ihtiyaç duyulan doğa ile yakınlaşma, mahalle ve sokak kavramları ile bağlam kuran komşuluk ilişkileri, geleneksel değer ve adetlerin gün yüzüne çıkması ile doğrudan orantılıdır. "Eskide yaşanan "yeni"yi tekrar deneyimleme firsatı bulan post insanın bundan sonraki süreçte yeni "Nesne"lere ihtiyacı vardır. Yöntemin son aşamasını oluşturan makro yapılandırma Aldo Rossi'nin şehir kaydında "Özne" ve “Nesne"lerin birbiri ile ilişkisinin koptuğu durumunu tanımlamaktadır. Modern Öncesi Dönem öznelerine benzerliğini gösteren günümüz öznelerinin ihtiyacı olan "Nesne"ler yine Modern Öncesi Dönem nesnelerine ihtiyaç duyacaktır ve bunun için "bellek" kavramına başvurulmalıdır. Bellek ise bizi tarihe ve yine aynı döneme yani Modern Öncesi Döneme götürecektir.

\section{Covid-19 Pandemisi}

Çeşitli dönemlerde meydana gelen farklı salgın hastalıklar toplumsal olarak gündelik yaşamı birebir etkilemekle kalmayarak yaşam formunu da dönüşüme uğratmaktadır. Bu dönüşümü sağlıklı gerçekleştirebilmek için uygun tasarılar oluşturulması gerekmektedir. Bir kırılma noktasını tanımlayan pandemi sürecine var olan düzene entegre edilebilecek yeni tasarım (nesne) toplum (özne) ile uyumlu olmalıdır. Bu durumda ilk olarak yapılması gereken, özne ve nesne ilişkilerini içinde barındıran bağlamı anlamaktır.

\section{Covid-19 ve Covid-19 Salginmın Kent/Kentsel Kamusal Alanlardaki Et- kisi}

Covid-19 salgınının ilk resmi vakası Çin eyaleti olan Wuhan şehrinde 2019 yılında ortaya çıkmış ve Çin 31 Aralık 2019 tarihinde bu bilgiyi Dünya Sağlık Örgütü ile paylaşmıştır. Örgüt Çin'i 7 Ocak 2020 tarihinde izole altına alınmıştır (Kaya ve Şimşek, 2020, s.998). Buna rağmen hastalık kısa sürede yayılarak dünya genelinde büyük bir paniğe yol açmıştır. Çin'in kendi bünyesinde getirdiği sokağa çıkma yasakları, seyahat kısıtlamaları ve kamusal alanların kapatılması üzerine sağlık alanında sadece hastane ve eczanelere karşılık günlük ihtiyaca istinaden marketlerin kullanılmasına izin verilmiş 
ve bu tedbirler yerine getirilmiştir. Türkiye'de ise ilk vakanın 11 Mart 2020'de aç1klanmasıyla beraber kademeli olarak çeşitli tedbirler alınmıştır (Özcü ve Atanur, 2020, s.245) 19. yüzyıldan beri süregelen kamusal alan ilişkilerindeki gevşeklik yaşanılan salgın ile beraber (Bilgin, 2020), kent ve kamusal alanların "herkese açık ve erişilebilir olma" ilkesini tamamen değiştirmiştir (Atanur, 2020, s.3). Öncelikli olarak alınan tedbirler arasında eğitim sisteminde okulların kapatılmış olması (Şekil 10. 17), spor ve sanat etkinliklerinin askıya alınmış olması, bir araya gelinebilecek ortak alanların kullanıldığı kamusal alanların kapatılması, ibadet yerlerindeki toplu ibadetlerin yasaklanması bulunmaktadır. Kapalı alanlar kullanıcıların birbirleri ile etkileşimde olduğu durumlarda hava akımı ve yüzeylerdeki virüslerin ve temaslarından ötürü tehdit unsuru oluşturmaktadır (Ak, 2020, s.42). Bu sebeple kentlerdeki büyük bir grup kalabalık nüfusun içerisine girmemek için daha çok evlerinde kalmayı tercih etmekte ve kentsel alanlar kullanılacaksa eğer daha geniş çerçevede açık alanlara ihtiyaç duyulmaktadırlar. Türkiye'de kullanıcıların büyük bir çoğunluğunun kapalı alan kullanımlarını oluşturan alışveriş merkezlerinin aktif kullanımı sebebi ile kısıtlamalar kapalı ticari alanlarda olmuştur (Şekil 10. 13, 14, 16). Bu durum toplumun alışveriş alışkanlıkların da değişikliğe sokmuştur. Değişen sistemde alışveriş internet üzerinden yapılan çevrimiçi bir sisteme dönüşmüştür. Evde kalma zorunluluğuna giren insan doğadan tamamen soyutlandığı için kısıtlamalar hafiflediği takdirde park ve bahçelere akın etmiştir (Şekil 10. 18). Şehrin yeşil alanlarının yetersizliği sebebi ile şehir dışı mülk sahipleri bu alanları tercih etmiş, şehirde kalanlar ise sosyal mesafe kurallarına tam olarak uyamamışlardır. Sosyal mesafe sınırından dolayı mağaza ve işletmeler sınırlı sayıda kişi alarak bu durum mekân girişlerinde sıralara sebep olmakta ve bu sıraların aralıklarının 1,5 metre mesafe sınırında kalması şartı aranmaktadır. Bunun kuralın yerine getirilmesi için ise çeşitli işaretleme yöntemleri kullanılmaktadır (Şekil 10. 15). Salgın devam ettiği takdirde bu alanlar için yeni bekleme alanları tasarlamak durumunda kalınabilir. Kentin önemli ağlarını ve trafik sorununu oluşturan ulaşım sistemi ise, kalabalık ortamdan uzak kalmaya çalışan kişisel aracını veya ticari araçları kullanmayı tercih eden kitleye karşılık toplu taşımayı kullanmak zorunda olan oldukça yoğun kitleyi oluşturmaktadır (Özcü ve Atanur, 2020, s.245). 


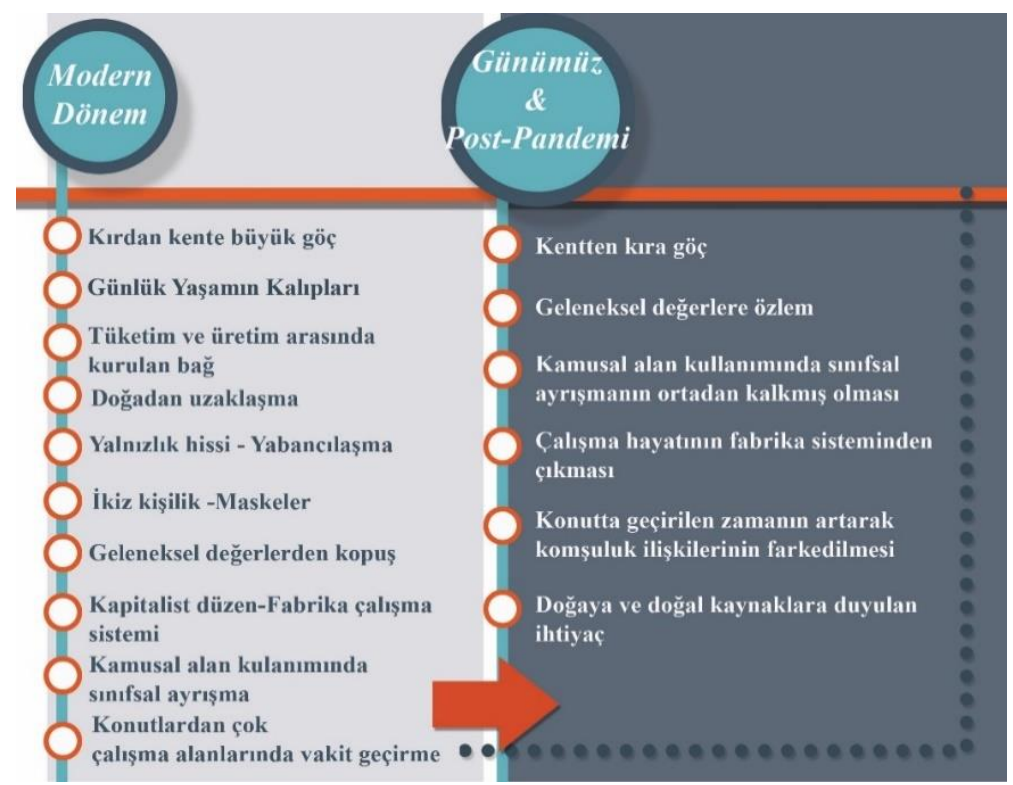

Şekil 9. Modern Dönem ve günümüz ilişkisi (Sertsarı, Birer, 2021)

Modern Dönem kırılmasına ait dönüşüm kavramlarını pasifize ederek karşısında eşleştirilecek dönüşümü Covid-19 pandemisi üzerinden görmek mümkündür (Şekil 8). Buradaki eşleştirme, salgının yaratmış olduğu ortamın bulaşma riski üzerinden kent kullanıcılarının ihtiyacı olan dönüşümü yansıtmaktadır. Kalabalık çalışma ortamlarına çözüm olarak sunulan mekân olan konut, aile bireylerini ayıran modern hayatın birleşme noktası olmuştur. Sosyal mesafelerin açlarak, kamusal alan kullanımlarının kısıtlanması ile birlikte konutlarda geçirilen zamanın artması, toplumsal ve geleneksel değerlerin varlığına farkındalık kazandırmıştır. Konutlardaki yaşam standartlarına karşılık da insan, ihtiyaç gereği açık alan ve doğal ortama mecbur bir varlık olduğunu kavramıştır. 

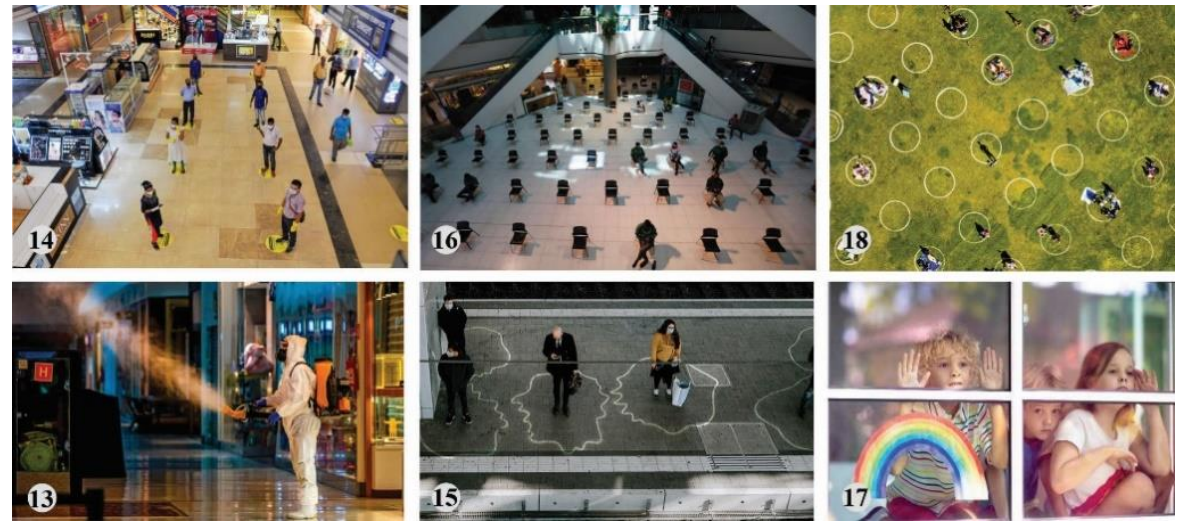

Şekil 10. 13- ("Record death tolls", 2020) 14-("Social distance at mall”, 2020) 15("Corona Lasers", 2021) 16- (Will the Shopping, 2020) 17-(Pandemi dönemi gençleri, 2020) 18- ("Human parking spots", 2020)

Günümüz kullanıc haritası içerisindeki bağlam (Şekil 9); Modern Dönemin etkilerinin üst üste eklenerek şekillendiği kullanıcı haritasını oluşturmaktadır. Bugün haritanın en genişlemiş kapsayıcı halini görmek mümkündür. Yoğun nüfusun gündelik hayatın içerisinde hızlı tüketim ortamını oluşturduğu, ulaşım ağlarının, konut, eğitim alanları ve kentin çeperinde kalan fabrika alanlarıyla birlikte oldukça geniş bir bölgeyi teşkil etmekte olduğu görülmektedir. Açık alan ve doğa ile ilişki kurmak için dahi araca binerek belli bir yolu kat etmek durumunda kalan kentli zamanını trafikte geçirmekte ve çok hızlı bir şekilde tüketimin içinde bulunmaktadır. Hem alışveriş hem de sosyalleşmek amacıyla AVM alanlarını kullanan yoğun nüfus, bu kadar kalabalığın içinde dahi sosyal mesafenin içinde kendini yalnız ve yabancılaşmış hisseden bir ortamın üyesidir.

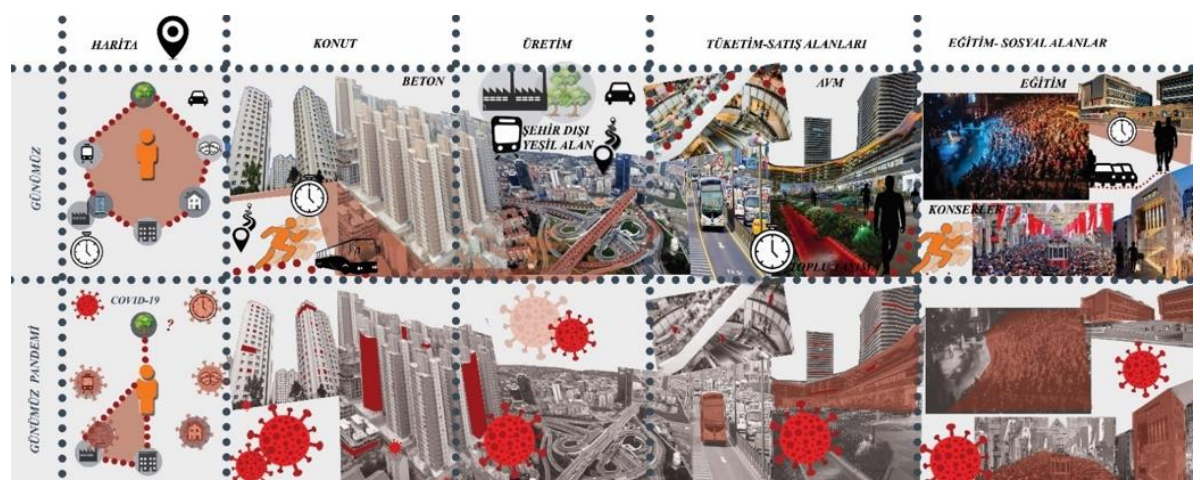

Şekil 11. Günümüz ve Günümüz Pandemik Dönem gündelik yaşam bağlamı (Sertsarı, 2021) 
Covid-19 Pandemisi sürecinde kent kullanıcısı artık çevresel ve sosyal bir determine ile yeni bir kullanım haritası belirler (Şekil 9). Bu haritaya göre çalışma ve eğitim sisteminin konutlara kaydırılması, toplu taşıma kullanımının ve sosyal alanların kullanımında risk faktörü yer aldığı için daha kısır bir ağlar bütünü oluşmuştur. İnsan ölçeğini aşan konut yapılarının içerisindeki nüfus kalabalıkları sebebiyle ortak kullanım alanlarında virüsün yayılma hızının çoğalma tehlikesine karşılık evde karantina süreçleri gerçekleşmektedir. Kapalı alanlardaki tüketim mekanlarını barındıran AVM yapıları için kurallar getirilerek, aktivitelerin gerçekleştirildiği kapalı alanlar kullanıma kapatılmış ve açık ortamlarda da mesafe kuralları getirilmiştir.

Sağlıklı ortamı sağlayabilmek adına getirilen kuralların tariflediği yeni bağlamın, Modern Dönem 'in kırılmasının değiştirdiği bağlamı tariflediği açıkça görülmektedir. Geçmişte yaşanan yaşamla kurulacak ilişkiyi aramak, toplum yaşamının sürdürülebilirliği açısından oldukça önemlidir. Var olan düzeni korumak hem kültür devamlılı̆̆ hem de Modern Dönem kırılmasının getirdiği olumsuz koşulları ortadan kaldırabilecektir. Bu açıdan bakıldığında kent/kentsel kamusal alan tasarımı için Pre-Modern hayatın gündelik yaşamını incelemek etkili bir çözümü oluşturacaktır.

\section{Modern Dönem Öncesi ve Covid-19 Pandemisi Kent/Kentsel Kamusal Alan Üzerinden İlişkisi}

Covid-19 Pandemisi sürecinde ele alınan bağlam; Modern Dönem öncesi ve günümüzde ortaya çıkan Covid-19 pandemi süreci arasındaki karşılaştırma şeklinde ele alınmıştır (Şekil 12). Bu karşılaştırmanın sebebi, pandemide virüsün tehdit ettiği ilgili başlıklar; konutlar ve açık alan ilişkileri, üretim ve tüketim mekanları ve bunların hepsini kapsayan kamusal alanlar ile kurulu bağlar incelendiğinde antivirüs ortamının Modern Dönem öncesinde bulunabilme olasılığıdır. 


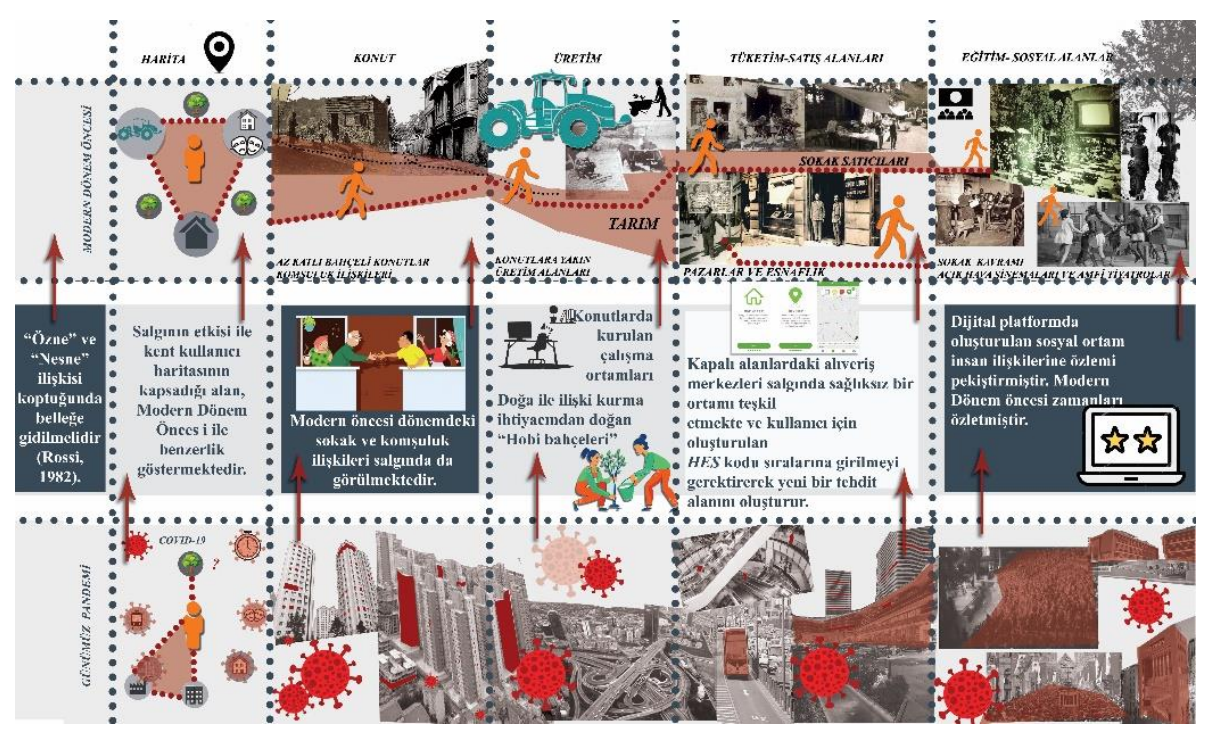

Şekil 12. Modern Dönem öncesi ve Covid-19 salgınının açık alanlar üzerinden ilişkisi

(Sertsarı, 2021)

Şekil 7 çalışması Modern öncesi insanının oluşturduğu gündelik yaşam bağlam haritası ile Covıd-19 pandemi dönemini yaşayan post insan figürü arasındaki bağlantıyı kurmaktadır. Harita pandeminin etkisinde sosyal mesafe içerikli getirilen kurallar doğrultusunda Modern Dönemde gelişmiş olan üretim alanlarını, tüketim mekanlarını ve sosyal alanları etkileyerek kullanıma dair kısıtlamaları barındırmaktadır. Oluşan bu kullanım haritası kısıtlamalarına bakıldığında benzerlik görülen Modern öncesi dönem hem üretim alanlarında hem de tüketim alanlarında açık alanı ve konut birimlerine yakınlığı ile dikkat çekmektedir. Toplumsal ilişkiler ağının içerisinde esnaf müşteri ilişkisi, mahalleli komşu ilişkisi ve bu ilişkilerin daha fazlasına ihtiyacın görüldüğü Covid-19 pandemisinde kentsel ve kamusal açık alan ihtiyaçlarını sosyolojik anlamda incelenmesi için de ayrıca bir çalışma alanı sunmaktadır. Çalışma ortamlarının büyük bir kısmının evlere taşındığı pandemide, Modern öncesi dönemin üretim alanlarının konutlara yakın olması ile benzerlik yaşanmakta ve bununla beraber yerleşim yerini güzelleştirme, doğa ile kaynaşma ihtiyacının insani durumu ile ekosisteme desteğin bilincine varılmaktadır. Kapalı ticari alanlar bulunduğu dönemin yaşamsal kalitesi içerisinde hava şartlarından ve dönemin güvenlik sorunlarını ele aldığından tercih edilmiş olabilirler, ancak pandemik kırılma bunlara karşı kavramları teşkil ettiğinden dolayı açık alanlarla etkileşim ve temiz hava ihtiyacı ile birlikte toplumun psikolojik olarak birbirine güvenine de 
ihtiyaç duyduğu ve bunu kuvvetlendirme isteği beraberinde gelmiştir. Dolayısı ile Post insanın uyanışını gerçekleştiren Covid-19 kırılmasının, oldukça yerinde ve etkileyiciliğini tüm kentsel öğelere temas ederek gerçekleştirdiği görülür.

\section{Bulgular: Aldo Rossi Söylem Analizinin Gelecek Zamana Dair Tasarım Referansları}

Rossi'nin söylem analizi üzerinden Covid-19 pandemisi kentsel/kamusal alan tasarım önerilerini Modern Dönem öncesi referansı ile irdelemek mümkündür (Şekil 13) Dönemler içerisinde "Nesneler" ve "Özneler" ilişki kurarak kendi bağlamlarını oluştururlar. Nesneler aktarılabilen şehirler, yapılar veya eşyalar olabilirken özneler ömürleri kadar bu bağlamı sürdürür ve nesneler ile ilişki halinde olurlar. Bağlam dönemin fonksiyonları içerisinde değişim ve dönüşüm yaşayarak çeşitli kırılma dönemlerine de sahne olur. Bu kırılmalar sebebi ile özneler ve nesneler zaman aşımına uğrayarak gerekli olan aktarımı sağlayamazlar. Bu durum Rossi'nin şehir kaydını da karmaşıklaştırır. 


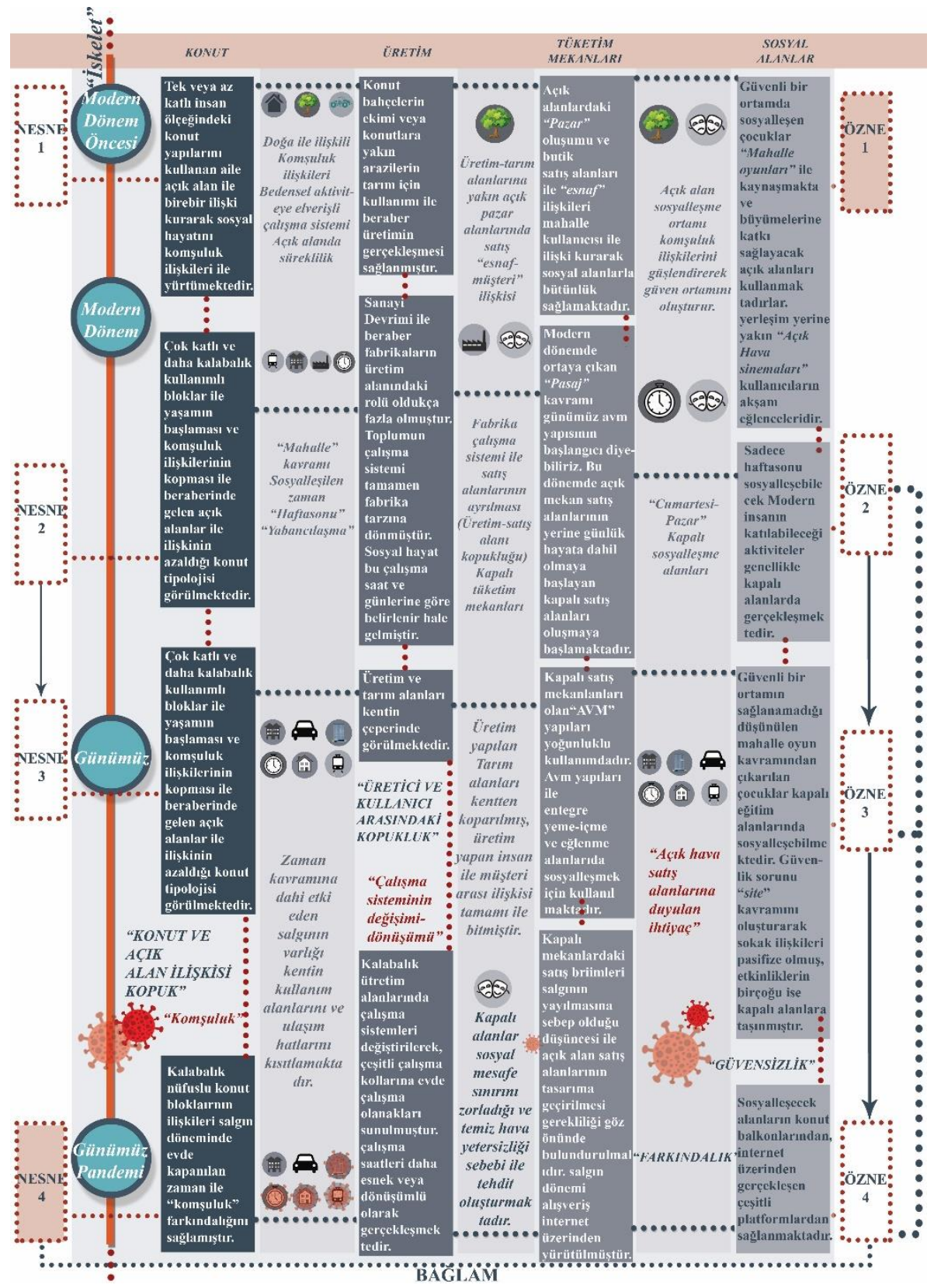

Şekil 13. Özne, Nesne ve Bağlam ilişkisinin Aldo Rossi Söylem Analizi

(Sertsarl, Birer, 2021)

Modern Dönem öncesi öznesi Modern Dönem kırılması ile beraber kendi geleneklerinden uzaklaşarak yeni bir özneyi oluşturur (Özne 2) ve bu 
dönemler arasında özneler arası bir kopukluk söz konusudur. Nesneler ise kırılmayı tarifleyen Modern Dönemde yenileri ile yer değiştirmiştir (Nesne 2). Kentsel olarak değişimin içerisinde aynı zamanda gündelik hayatın kullanımlarına bağlı olarak teknolojik sistemleri de görebilmek mümkündür. Dolayısı ile Modern Dönem kırılması nesne ve öznelerin devamlılığını etkilemiştir. Modern Dönem sonrası ise, üzerine yenilerin geldiği dönüşümü oluşturmaktadır. Modern Dönem insanı olarak tanımlanan Özne 2, sonraki süreçler içerisinde post insan diye tanımlayabilecek kendi bilinç, etik ve ahlaki değerlerinin önüne geçemeyen ve düzenin determinizm etkisinde kalan Özne 3 ve Özne 4 karakterini ortaya çıkarmaktadır. Nesneler de aynı özneler gibi Modern Dönemden sonra geleceğe aktarılan durumda iken Covid-19 pandemisi kırılması ile beraber nesneler arasındaki bağ da kopmuştur. Nesneler bu dönemde salgindan ötürü tehdit oluşturmakta, özellikle toplu kullanım alanları olan kentsel/kamusal alanlarda yeni bir düzenlemeye ihtiyaç duyulmaktadır. Post pandemik nesne olarak tanımlanan (Şekil 13) Nesne 4, Covid-19 pandemisi nesnelerini meydana getirmekte ve salgin için oluşturulan kentsel/kamusal kurallarını içinde barındırırken post pandemik döneme ise tasarım referansını vermektedir. Rossi'nin görüşüne göre özne ve nesne ilişkilerinin birbirinden kopması halinde çözümü iskelet kavramı ile kayıt edilen yaşanmış bellekte bulmak mümkündür. Bu görüşe göre kaynakça tarihin içerisindeki ilişki ağlarındadır.

Rossi söylemine göre özne ve nesnelerin ilişkisi bağlamı oluştururken bu kavramlar sürekli olarak yer değiştirmektedir. Covid-19 pandemi sürecini yaşayan post insan gündelik hayatta Modern Dönem kırılmasına karşılık gelebilecek sosyolojik bir ilişki ağına girmiştir. Özne yaşanan toplumsal ilişkiler ile beraber Modern Dönem öncesine giderken, nesneler pandemi içerisinde salgın tehdidini yaymaya devam etmekte ve bunu durdurabilmek ve duruma çözüm üretebilmek adına yeni bağlamın kurulması gerekmektedir. Yeni bağlamı Modern Dönem öncesinde bulan çalışmada, Modern Dönem öncesi öznesi bağlamı içerisinde satış alanlarının açık alanda oluşu salgının tehdidini önlerken, toplumsal olarak geleneklerin, üretici ve satıcı arasındaki ilişkinin tekrardan kuvvetlenmesi için yeni kapıları açar. Esnaf ilişkileri içerisinde butik satışların gerçekleşmesi sokak kültürünü ve komşuların birbirleri ile tanışma fırsatını sağlarken, güvenlik duygusun da attırabileceği düşünülmektedir. Açık hava etkinliklerinde sosyalleşmek hem temiz hava ile ilişkili hem de sosyal hayatı besleyen aktiviteler arasındadır. Dolayısı ile şehir olarak tanımlanabilecek nesneye karşılık özne ve nesnele- 
rin ilişkileri yeni bağlamını kurarken pandemi için tasarı önerisini sunmaktadır (Şekil 14).
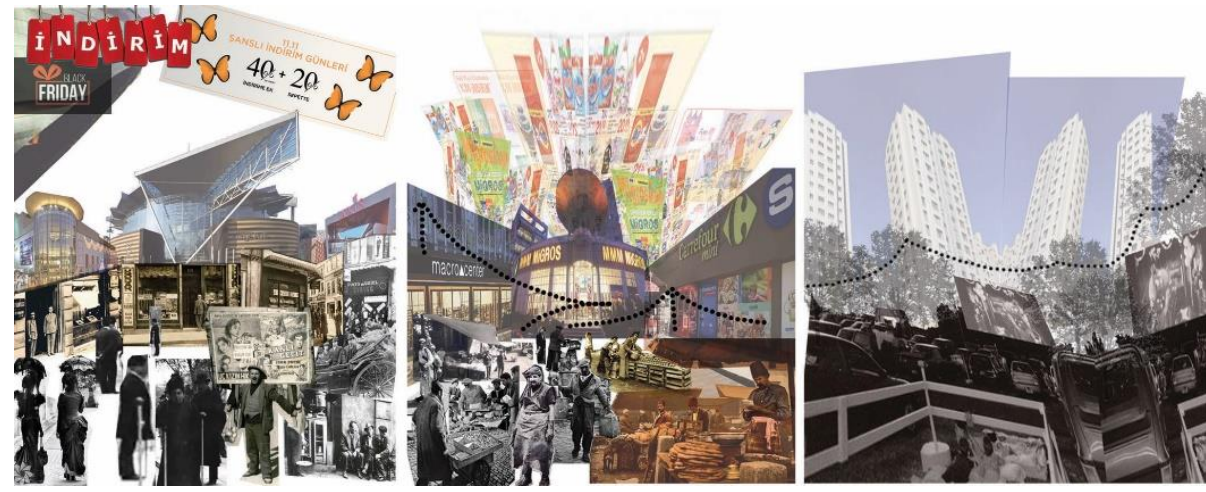

Şekil 14. Modern insanın geri dönüşü. Unutulan yeni nesneler ve bağlam (Sertsarı, 2021)

Sonuç olarak post pandemik dönem için oluşturulacak tasarım önerilerine referans veren Modern Öncesi Dönem Rossi'nin özne-nesne ve bağlam aforizması üzerinden okunarak elde edilen bulgularda, öznelerin (kent kullanıcıları) nesneler ile (kent/kamusal alan) ilişkilerinin bağlamını oluşturan sistematik kurgunun birbirinden koptuğu gözlemlenmiştir. Rossi' nin bu aforizmasına göre kopuşun yaşandığı durumda tarihte kaydedilen şehir belleğine gidilmesi ve gelecek referansın bellekten okunması gerektiği ortaya çıkmaktadır. Çalışmada, Modern Dönem öncesi bağlamına gidilerek kent kullanıcısının kullanım haritası incelenmiş, açık alanlar ile kurmuş olduğu ilişkinin Covid -19 pandemisi için oluşturulan sosyal mesafe kurallarının sınırlarını oluşturduğu ve bu sınırları kullanarak geliştirilecek tasarımın Post Pandemik dönem içinde geçerli olabileceği bulgularına varılmıştır (Şekil 15).

\section{Tartışma/Sonuç}

Modern Dönem kırılmasından sonra gelen süreç içerisinde yaşamsal dönüşümler modern insanı post modern insana çevirmiş, düşünebilen ve kendi etik değerlerini yerine getirebilen insan bu dönüşüm içerisinde dayatılan kapitalist sistemin içinde erirken değerlerini kaybetmiştir. Yapılan çalışma doğrultusunda, Modern Dönem Öncesi kurulan toplumsal ilişkilerin, yap1laşma ve açı alanların birbirleriyle kurduğu ilişkiler ile doğrudan orantılı olduğu görülmektedir. Bu sebeple yaşanan pandemiler mekanları değiştirerek "Öteki mekân" haline gelmesini sağlayacak potansiyeli de içinde barındırmaktadır. Mekânı ötekileştirmek ve dönüşümü sağlamak için oluşturu- 
lacak sağlıklı çözüm önerileri, post pandemi döneminde de kullanılabilen sürdürülebilirlikte olmalıdır. Devamlılığı sağlamak için ise, yeni bir söz söylemek yerine kaybedilen değerleri göz önünde bulundurmak önemlidir.

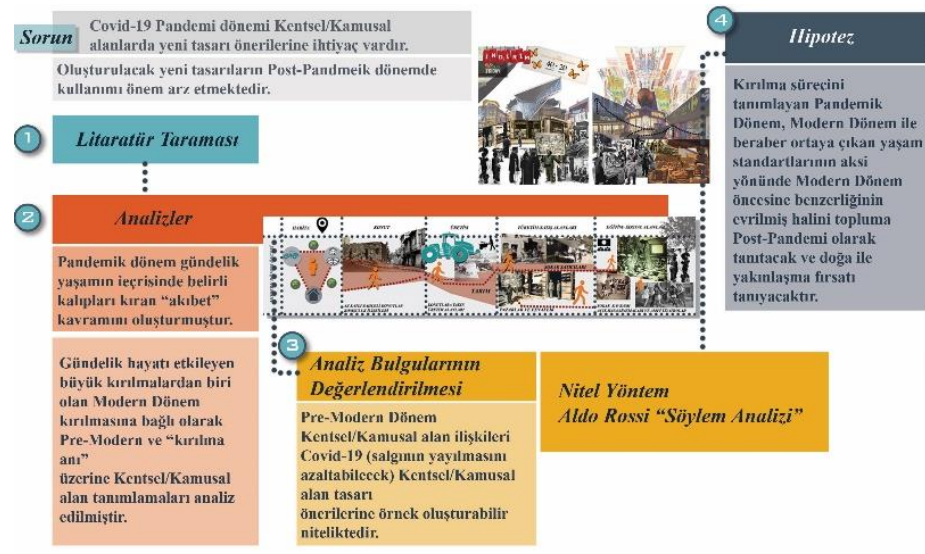

Şekil 15. Sonuç Diyagramı (Sertsarı, Birer, 2021)

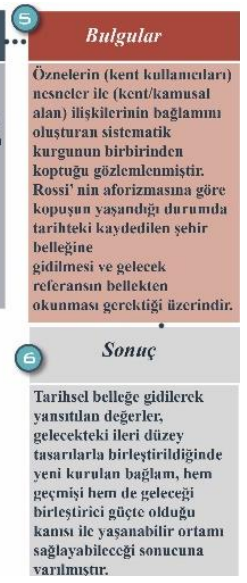

varilmistir.

Bu çalışma sonucunda toplumsal, sosyolojik ve psikolojik olarak değişimin var olan bellekte bulunduğu görüşü ile gündelik hayatın kalitesinin arttırılabileceği, çevresel faktörlerin değerinin bilinciyle birlikte hem fiziksel hem de sosyal birleşimin gerçekleşebileceği öngörüsü tartısmaya açılmıştır. Tarihsel belleğe gidilerek yansıtılan değerler, gelecekteki tasarımlarla birleştiğinde yeni kurulan bağlamın hem geçmişi hem de geleceği birleştirici güçte olduğu, bu durumun toplumsal belleğin de sürekliliğini yansıtacağı ortadadir. 


\section{Extended Abstract}

\section{Reading Post Pandemic Period Public Space Design through Aldo Rossi's Aphorism}

\author{
Elif Sertsarı Aslan \\ ORCID: 0000-0003-3947-0440
}

\author{
Emel Birer \\ ORCID: 0000-0003-0152-3690
}

The transformation process of order-determining nature, which lasted for throughout the centuries and is also slow that human cannot notice, was given to human beings by the instruments of modernity, therefore humanity became the order-determiner. Having said that, this moved the concept of change to an experimental field and accelerated it to a movement that could not have been witnessed before. The Modern Period affected urban and rural life socially and sociologically, leaving many damages while opening up to innovations and this damage created a situation that was difficult to improve over time. Especially the living standards of the Modern Period led to irreversible consumption on ecology, disconnected lives from nature, changing the emotional, ethical values of the modern human figure and becoming the new post-human. While the study states that the concept that will improve the negative conditions added to lives of the Modern Period is a "fate", it conciders the concept of "fate" as a reason to create a new spatial experience, according to the definition of Stavrides (Stavrides, 2016, p.70). This concideration also provides an opportunity for urban designers to reshape the physical environment of cities proactively and fundamentally. Therefore, the desires to transform the negativities which the breaking points (periodic changes, epidemics, migration, etc.) led, based on certain reasons into a livable environment constitute the questions of this study and they are significant for the solutions to be came up with. Accordingly, the answer to the question "Is it possible to find references from the past to the designs that can be foreseen for urban and public spaces to be designed with the Covid-19 breaking point?" is rather than saying a new word, however will allow to accommodate a confirmed 
livability experience. This opportunity is crucial for the sustainability of postpandemic period urban and public spaces. The hypothesis that was created concerning the study question is obtained from the literature review questioning the breaking points with the concept of "fate", and the questionings emphasize that the sample for breaking point is "Modern Period". The relations of urban and public space before the Modern Period contains an important discovery that also constitutes the hypothesis. The hypothesis developed argues that the pre-modern conditions, which support the negative sides of the similarities of the "Pandemic Period" with another breaking point "Modern Period" will solve the problems experienced when combined with today's developing conditions. The Modern Period constituted the breaking point where the society infiltrated its daily life under the influence of the Industrial Revolution, which was particularly on the rise with the Reform and Renaissance movements in Europe, creating changes in economic, political, sociological, psychological terms. According to Stavrides, who defined the breaking point as "fate" (Stavrides, 2016, p.70), The fate is a concept that is considered as necessary for the crackling of a city's immutable structure and stereotyping order. When it is associated with today's breaking point, it can be implied that it will correspond to the "Covid-19 Pandemic". This study aims to reveal the possible benefits of the pandemic process and the fate arising from the re-occurrence of the breaking point in the redesign of public spaces. In Pre-Modern Period, urban and public space relations which may be a reference to the proposals, are read through Aldo Rossi's aphorism "Subject-Object and Context relationship" (Rossi, 1982, p.4), which determines the method of discourse analysis of the study and synthesizes its relationship with the post-pandemic period. When examined through Rossi's discourse analysis, it is possible to analyze the Covid-19 pandemic urban/public space design proposals with preModern Period reference. During periods, "Objects" and "Subjects" form their own contexts by establishing relationships. Context also occurs in various periods of breakdown by experiencing change and transformation within the functions of the period. Due to these fractures, subjects and objects cannot provide the necessary transfer by timed out. This complicates Aldo Rossi's city record. Aldo Rossi (Rossi, 1982, p.4) emphasizes that if "Objects" (cities) cannot connect with "Subjects" (city users), "history" must be used to create the necessary "context". The rhetoric here consists of all relational inputs of life, such as social, political, cultural, and economic fields. The findings obtained from the subjectobject and context aphorism of Pre-Modern Period Rossi, which refers to the design proposals to be created for the post-pandemic period showed that the systematic fiction, which forms the context of the relationship between the sub- 
jects (city users) and the objects (urban/public space) was detached from each other. According to Rossi's aphorism, when the rupture occurs, the recorded city memory in history should be visited and the following reference should be read from memory. In this study, evaluating the pre-Modern Period context, the city user's map was examined and was found out that the relationship with open spaces constituted the limits of the social distancing rules created for the Covid-19 pandemic and that the potential design using these limits may be valid during the Post Pandemic period. As a result of this study, the idea justifies that the social, sociological and psychological change stands in existed memory and the idea that the quality of daily life can be improved, and that both physical and environmental combinations can occur with the awareness of the value of environmental factors has been discussed. It needs to be expressed that the newly established context, coupled with future designs, is strong enough to unite both the past and the future, reflecting the continuity of social memory.

\section{Kaynakça/References}

Abusaada, H. ve Elshater, A. (2020). Covid-19's challenges to urbanism: social distancing and the phenomenon of boredom in urban spaces. Journal of urbanism: International research on placemaking and urban sustainability, p.1-3.

Adilhan, Ö. ve Ünverdi, L. (2018). Kentsel yenileme sürecinde kentsel tasarımın önemi: Aydın-Söke örneği. Adnan Menderes Üniversitesi Sosyal Bilimler Enstitüsü Dergisi, 5(1), s.226-261.

Acar, Z. B. (2017). Modern dünya, gündelik yaşam ve modern özne. Farklılıklar, çatışmalar ve eylemlilikler çağında sosyoloji. VIII. Ulusal Sosyoloji kongresi. Ankara: Odtü.

AK, Özlem. (2020). Pandemi mimarisi, TÜBİTAK Bilim ve Teknik Dergisi. Ağustos 2020, s.42-45.

Artun, N. ve Ojalvo, R. O. Y. S. İ. (Der.). (2012). Arzu mimarlığı. İstanbul: İletişim Yayıncilik.

Aydoğan, D. (2013). Gündelik yaşam pratiklerinde anlamı inşa eden toplumsal dinamikler. Sosyoloji Dergisi, (28), s.1-18.

Baba, E. (2020). İdeal kent arayışında mimari ütopyalar. İstanbul: Yem Yayınevi.

Baudelaire, C. (2009). Modern hayatın ressamı. Berktay, A. (Çev). İstanbul: İletişim Yayınları.

Berman, M. (1994). Katı olan her şey buharlaşıyor. Ü. Altuğ ve B. Peker (Çev). İstanbul: İletişim. (1982)

Bilgin, İ. (2020). Karantina sonrasına dair tahayyüllerimiz. Mimarlık Dergisi, (414), Temmuz - Ağustos, s.1.

Bozdoğan, S. (2003). Sonuç modernizm ve ulusun inşası. Arkitera Diyalog.

Caen et ses grands magasins. (2017, 31 Mayı). Erişim adresi: http://www.cadomus.org/articles/caen-et-ses-grands-magasins 
Certeau, M., Giard, L., Mayol, P. (2009). Gündelik hayatın keşfi-II. Konut, mutfak işleri. Eroğlu, Ç., ataçay, E. (Çev.) Ankara: Dost Kitapevi yayınları. (1990).

Corona Lasers, Visual representation of social distancing system. Photo: Joery Verweij (2021, Ocak). Erişim adresi: https://www.damnmagazine.net/company_news/functional-social-distancingart/

Çelik, H., Ekşi, H. (2008). Söylem analizi. Marmara Üniversitesi Atatürk Ĕ̆itim Fakültesi Eğitim Bilimleri Dergisi, 27 (27), s.99-117.

Doğrucan, P.(2013-2014), Ütopyalar hep var! Almanak, İstanbul Teknik Üniversitesi, s.6-17 Étonnant : la trottinette électrique a déjà 100 ans Étonnant : la trottinette électrique a déjà 100 ans". (2019, 31 Ocak). Erişim adresi: https://detours.canal.fr/etonnanttrottinette-electrique-a-deja-100-ans/

Harvey, D. (2008). Umut mekânları. Gambetti, Z. (Çev.) İstanbul: Metis Yayınları. (2000).

Habermas, J. (1994). The philosophical discourse of modernity- Twelve lectures. Cambridge, Oxford: Polity Press.

Habermas, J. (1996). "Modernity: An unfinished project", Habermas and the unfinished project of modernity: critical essays on the philosophical discourse of modernity. Maurizio passerin d'entreves ve Seyla Benhabib (Der.) Cambridge: Polity Press.

Habermas, J. (2002). Öteki olmak, ötekiyle yaşamak. Aka,İ. (Çev.) İstanbul: Yapı kredi yayınları (1997).

Hays, K. M. (2015). Mimarlı̆̆ı arzusu: Geç avangardı okumak. Gambetti, Z. (Çev.) Atmaca, V., Demirhan, B. (Çev.) İstanbul : YEM Yayınları. (2010)

'Human parking spots' could help Philly residents keep social distance at parks. (2020, 19 Mayıs). Erişim adresi: https://whyy.org/articles/human-parking-spotscould-help-philly-residents-keep-social-distance-at-parks/

Intérieur du passage Bellivet, bimbeloterie les Touristes. (2017, 31 Mayıs). Erişim adresi: http://www.cadomus.org/articles/caen-et-ses-grands-magasins

Kaldık, B. (2017). Türkiye'de modernite bağlamında Kent (li) leşme. PESA Uluslararası Sosyal Araştırmalar Dergisi, 3(4), 27-41.

Kaya, İ. ve Şimşek, E. G. (2020). Dünya Sağlık Örgütü ve Uluslararasi Sağlık Tüzügü: Covid-19 örneğinde Uluslararası hukukta salgın hastalıklarla mücadele. İstanbul Hukuk Mecmuası 78 (2), 983-1007

Lefebvre, H. (2013). Kentsel deorim. İstanbul: Sel Yayıncllk. Sezer, S. (Çev.), (1970).

Lefebvre, H. (2015). Şehir hakkı. İstanbul: Sel Yayıncllı. Ergüden, I. (Çev.), (1967).

Le Palais-Royal, havre de la séduction à Paris. (2016, 16 Mart). Erişim adresi: http://bluelionmobiletours.blogspot.com/2016/03/le-palais-royal-havre-de-laseduction.html

Les galeries du Palais Royal en 1800 (C) Gallica / BnF". (2021) Erişim adresi: https://www.pariszigzag.fr/secret/histoire-insolite-paris/les-marchandes-d-amourdu-palais-royal

Lithographie imprimerie oisselet dans passage . (2016, 29 Ocak). Erişim adresi: https://www.cparama.com/forum/viewtopic.php?p=111661\&sid=46f3458e1717d04 1480ced09c67ecc67\#p111661 
L'Illustration $\quad(2018, \quad 2 \quad$ Nisan). $\quad 2 \quad$ Erişim adresi: https://wallhaveni.blogspot.com/2018/04/l-illustration.html adresinden 2 Şubat 2021 tarihinde erişildi.

Mon Oncle, (2010, 6 Mart). Erişim adresi: https://criterionaffection.wordpress.com/2010/06/03/111-mon-oncle/

Olgun, İ., Dinç, S., Çılgın, K. (2020). Pandemide ve Post-pandemide toplum ve mekân: Görüşler, Öngörüler, Öneriler. Sprektrum tasarım rehberleri, (02).

Özcü, A., Atanur Sayan, G. (2020). Kovid-19 pandemisinin kent yaşamina etkisi: kamusal alan üzerine değerlendirmeler. Paradoks ekonomi, sosyoloji ve politika dergisi. (16), (2), s.237-250.

Özdemir, S. F. ve Gökmen Karahan, M. (2016). Lojistiğin evrimi ve Türkiye'deki önlisans ve lisans programları yönünden lojistik öğretimi. Niğde Üniversitesi İktisadi ve İdari Bilimler Fakültesi Dergisi, Temmuz, 2016; 9(3)

Pandemi dönemi gençleri ve çocukları nasıl etkiledi? (2020, 12 Mayıs). Erişim adresi: https:/gelisim.edu.tr/haber/pandemi-donemi-gencleri-ve-cocuklari-nasil-etkiledi

Record death tolls in Mexico and Brazil add to fears of Covid-19 surge in Latin America. (2020, 13 Mayis). Erişim adresi: https://www.theguardian.com/world/2020/may/13/brazil-mexico-coronaviruspandemic-latin-america

Rossi, A., (1982). The architecture of the city . Eisenman, P. (Çev.). Cambridge, MA: MIT press. (1978).

Sözen, E. (1999). Söylem: belirsizlik, mübadele, bilgi, güç ve refleksivite. Istanbul: Paradigma Yayınları.

Stavrides, S. (2016). Kentsel heterotopya: özgürleşme mekânı olarak eşikler kentine doğru. İstanbul: Sel yayıncllık. Karatay, A. (Çev.), (2010).

Şimşek, A. (2008). Habermas ve "modernite" kavramı. Politika Dergisi sitesi, http://www.politikadergisi.com.

Social distance at mall. (2020, 09 Haziran). Erişim adresi: https:/economictimes.indiatimes.com/news/politics-and-nation/the-unlocking-ofmalls-restaurants-see-how-they-look-like-now/tape-markings-onurinals/slideshow/76279489.cms

Soja, E. W. (2017). Postmodern coğrafyalar. Eleştirel toplumsal teoride mekânın yeniden ileri sürülmesi. İstanbul: Sel Yayıncllı/Kentsel. Yunus, Ç. (Çev.), (1989).

Will the Shopping Mall Look the Same After COVID-19? (2020, 8 Nisan). Erişim adresi: https://sourcingjournal.com/topics/retail/coronavirus-shopping-mall-retailrsr-mckinsey-american-dream-experiential-bopis-204489/

Worker feeding machine. Still from Charlie Chaplin's Modern Times s (1936). (2011). Erişim adresi: https://www.researchgate.net/figure/Worker-feeding-machine-Still from-Charlie-Chaplins-Modern-Times-s-1936_fig1_227229384

1768-1771: Sanayi Devrimi'nin yükselişi - Gérard Vindt. (2019, 15 Eylül). Erişim adresi: https://sendika.org/2019/09/1768-1771-sanayi-devriminin-yukselisi-gerardvindt-561314/ 